\title{
Investigating the effect of Professional Ethics and Personal Moral Philosophy on Auditors' Fraud Detection Capability according to moderating role of Professional Skepticism
}

\author{
Mohammad Pashaei Fashtali \\ Ph.D. Student of accounting, Faculty of Accounting and Management, Rasht \\ Branch, Islamic Azad University, Rasht, Iran \\ (Mohamadpashei67@gmail.com) \\ Keihan Azadi Hir* \\ Assistant Professor,Faculty of Accounting and Management, Rasht Branch, \\ Islamic Azad University, Rasht, Iran(Corresponding Author), \\ ka.cpa2012@yahoo.com \\ Mohamadreza Vatanparast \\ Assistant Professor, Faculty of Accounting and Management, Rasht Branch, \\ Islamic Azad University, Rasht, Iran(Vatanparast@iaurasht.ac.ir)
}

\begin{abstract}
:
Recent years studies show that external auditing occupies a low position (eighth place) among the methods of detecting fraud; as a result, it is important to examine which factors can improve external auditors' performance in detecting fraud. Therefore, the goal of this research is to study the effect of professional ethics and personal moral philosophy (subjective norm) and professional skepticism (attitude towards behavior) on external auditors' performance fraud detecting based on theory of planned behavior. This research is categorized as an applied one. Studying literature review, research data have been collected by a questionnaire. The statistical sample using cluster sampling method includes 159 private and public sector auditors and research period is dated during 2020. Data analyzing utilized by partial least squares (PLS) through Smart-PLS2 software. The results show that professional ethics and the ethical orientation of idealism have positive direct and indirect effect on the Fraud Detection Capability through mediator variable of professional skepticism. Moreover, ethical orientation of relativism has direct negative effect on fraud detecting
\end{abstract}


Semiannually journal of Value \& Behavioral Accounting dof $10.52547 /$ aapc.5.10.319

capability; besides ethical orientation of relativism has indirect effect on fraud detecting capability through mediator variable of professional skepticism.

Keywords: Fraud Detection Capability, Professional Ethics, Personal Moral Philosophy, Professional Skepticism, Theory of Planned Behavior

\section{Copyrights (c) (1)}

This license only allowing others to download your works and share them with others as long as they credit you, but they can't change them in any way or use them commercial. 
مقاله يُؤوهشى

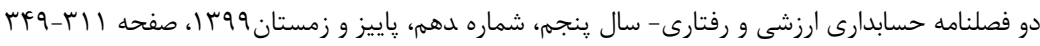

\section{بررسى ثاثير اخلاق حرفهاى و فلسفه اخلاقى شخصى بر توانايى كشف تقلب حسابر س با توجه به نقش ميانجى ترديد حرفهاى}

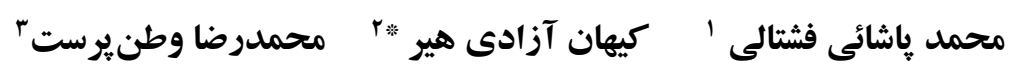

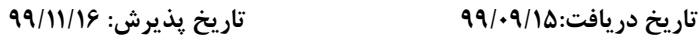

جكيده

مطالعات انجام شده در سالهاى اخير نشان مىدهد كه در بين روشهاى كشف تقلب، حسابرسى

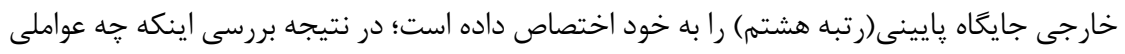

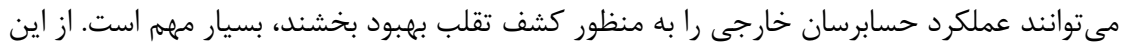

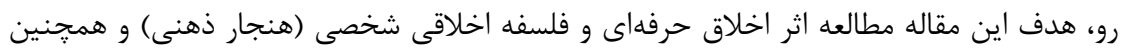

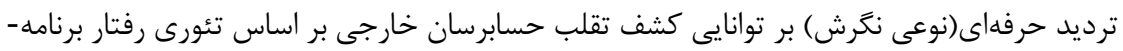

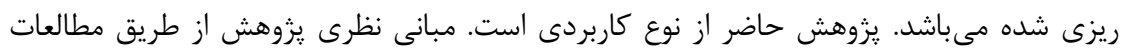

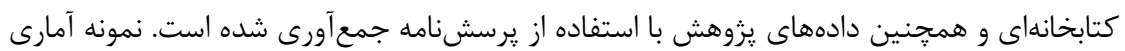

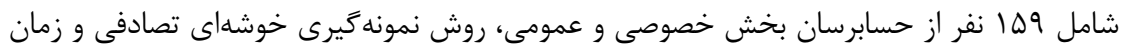

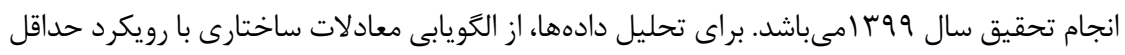

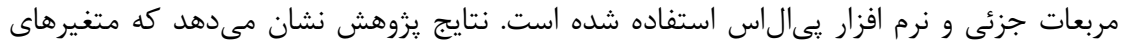

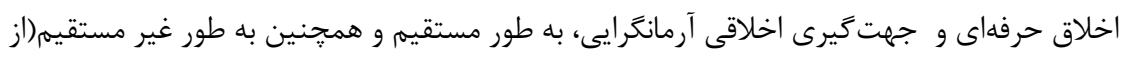

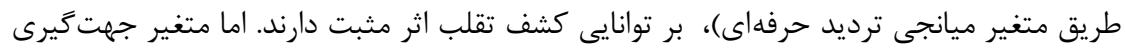

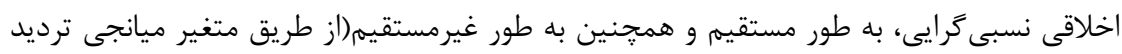
حرفهاى) بر توانايى كشف تقلب برائ اثر منفى مي كذارد. وازكًان كليدى: توانيى كشف تقلب، اخلاق حرفهاى، فلسفه اخلاقى شخصى، ترديد حرفهاى، تئورى رفتار برنامهريزى شده

\footnotetext{
'دانشجوى دكترى، كروه حسابدارى، واحد رشت، دانشكاه آزاد اسلامى، رشت، ايران Mohamadpashei67@gmail.com "استاديار كروه حسابدارى دانشكاه آزاد اسلامى واحد رشت، رشت، ايران(نويسنده مسئول)، kacpa2012@yahoo.com Vatanparast@iaurasht.ac.ir استاديار كروه حسابدارى، واحد رشت، دانشكاه آزاد اسلامى، رشت، ايران
} 
نكَرانى درخصوص تقلب روبه افزايش است. كزارش اخير انجمن بازرسان رسمى تقلب' در درد

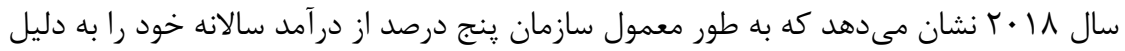

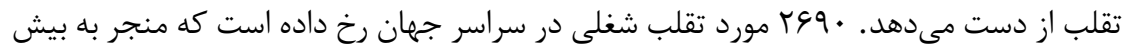

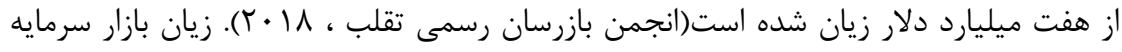

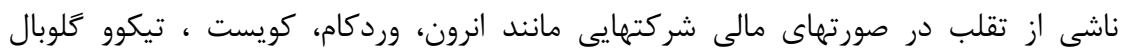

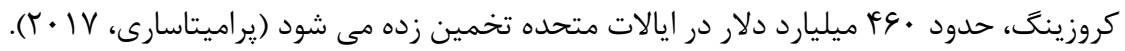

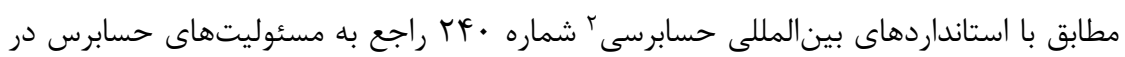

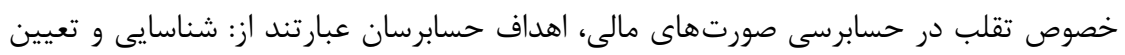

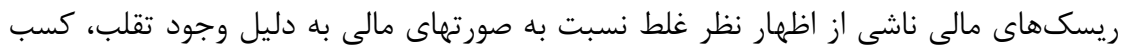

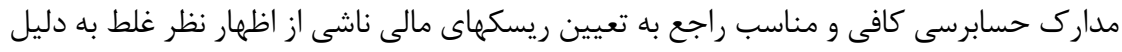

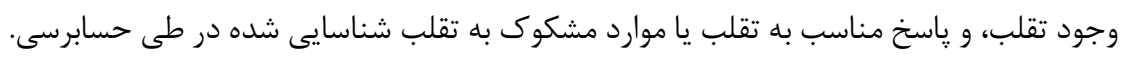
اين اهداف با طراحى و اجراى ياسخهاى مناسب در برابر خطرات تقلب قابل دستيابى است(هيات

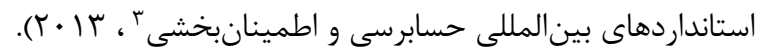

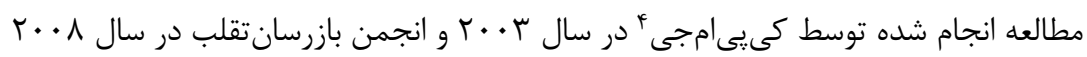

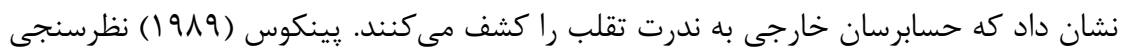

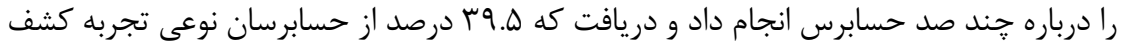

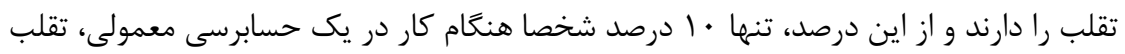

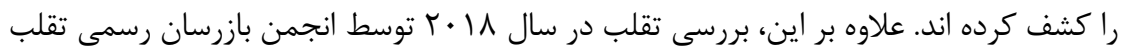

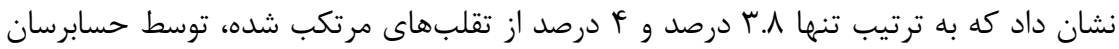

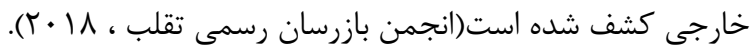

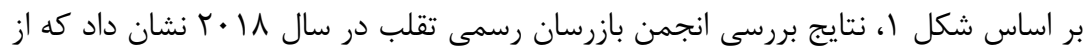

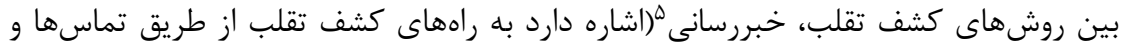

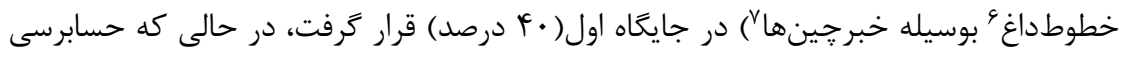

\footnotetext{
${ }^{1}$ Association of Certified Fraud Examiners (ACFE)

${ }^{2}$ International Standards of Auditing (ISA) 240

${ }^{3}$ The International Auditing and Assurance Standards Board (IAASB)

${ }^{4} \mathrm{KPMG}$

${ }^{5}$ Tip

${ }^{6}$ Hotlines

${ }^{7}$ Whistle-blowers
} 
ياشائى فشتالى و همكاران، بررسى تاثير اخلاق حرفه اى و فلسفه اخلاقى شخصى بر توانايى كثف تقلب... ساس

خارجى جايخاه هشتم را به خود اختصاص داد. درجه پإيين تشخيص تقلب توسط حسابرسان

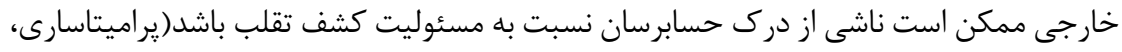

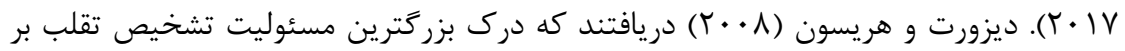

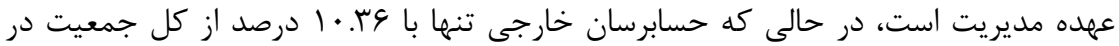
جايغاه جهارم قرار داشتند.

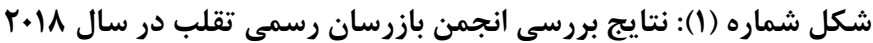

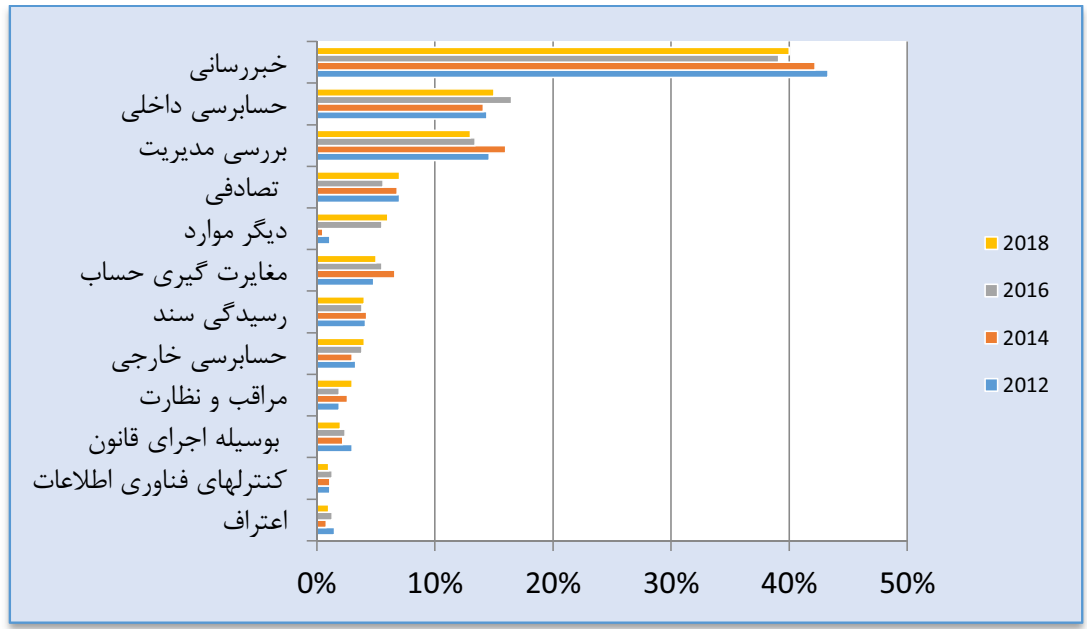

آمارهاى كشـورهاى توسعه يافته حاكى است كه به طــور ميانكين در حدود V درصــد در آمد

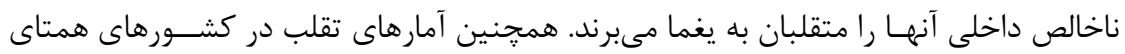

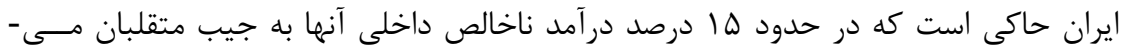

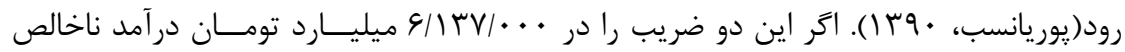

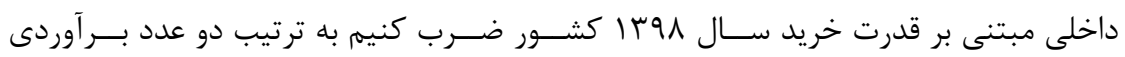

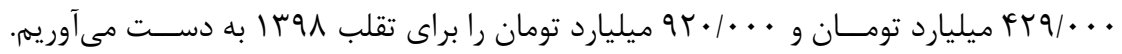

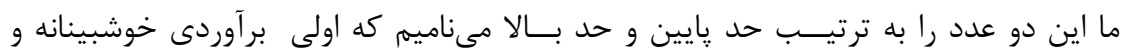

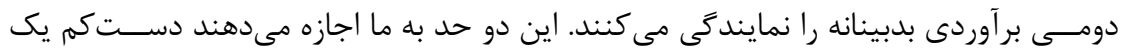

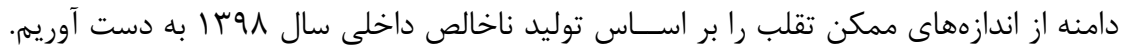

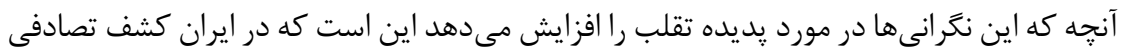

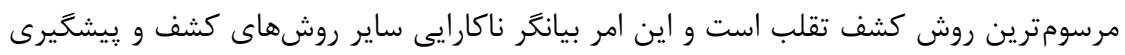

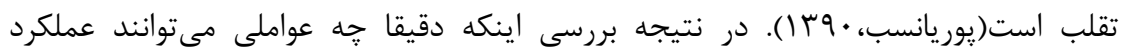
حسابرسان خارجى را بهبود ببخشند، مهم است. 
هدف اين مقاله توضيح تفاوتهاى رفتارى حسابرسان طبق تئورىرفتاربرنامهريزىشده' مى-

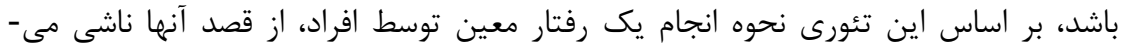

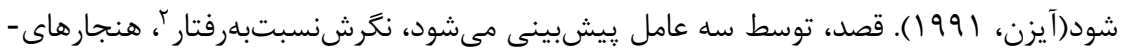

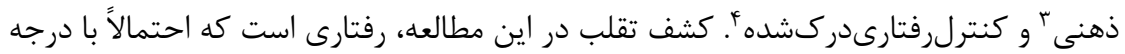

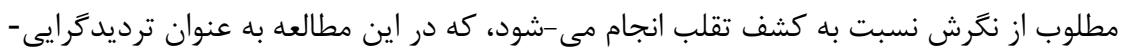

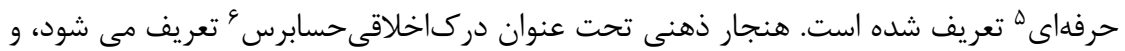

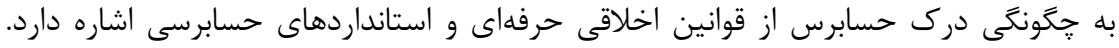

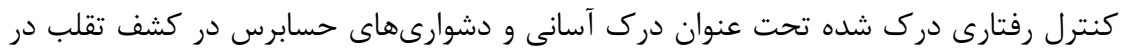

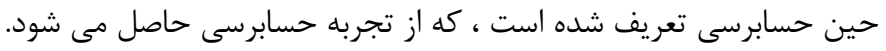
اهميت يزوهش حاضر بررسى نقش ابعاد اخلاقى بر توانايى كشف تقلب حسابرسان خارجى

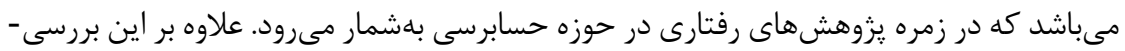

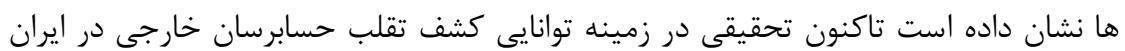

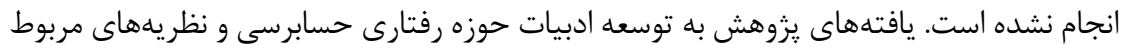

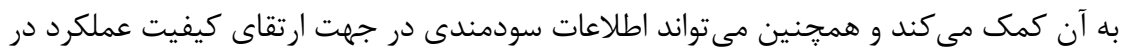

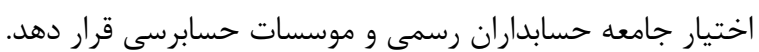

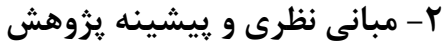

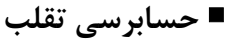

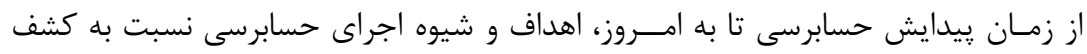

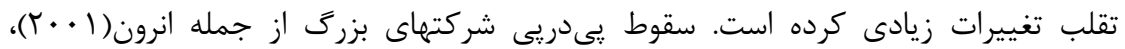

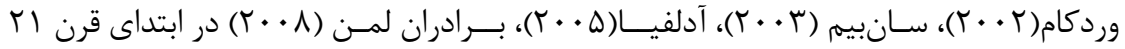

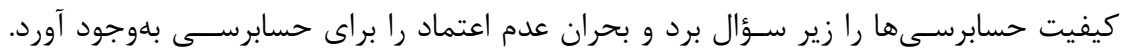

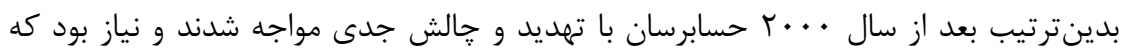

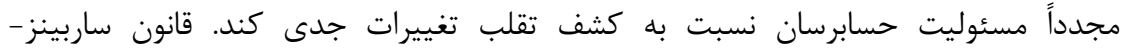

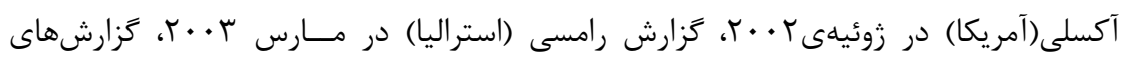

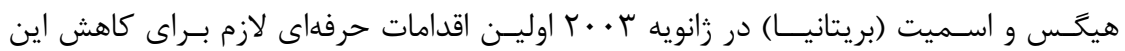

${ }^{1}$ Theory of Planned Behavior

2 attitude towards behavior

${ }^{3}$ subjective norms

${ }^{4}$ perceived behavioral control

${ }^{5}$ professional skepticism

${ }^{6}$ auditor's ethical perception 


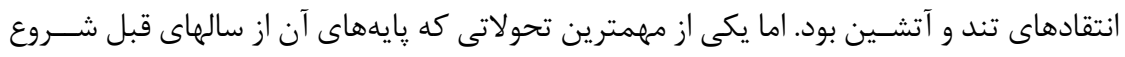

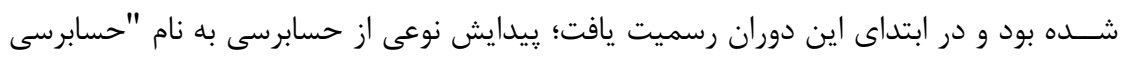

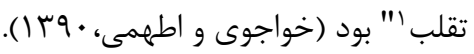

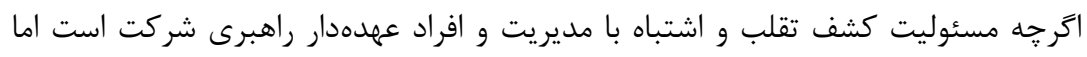

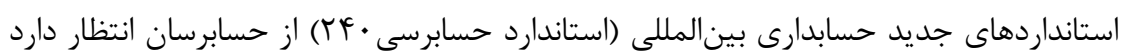

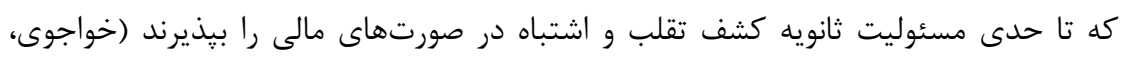

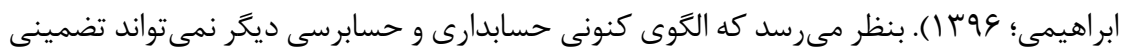

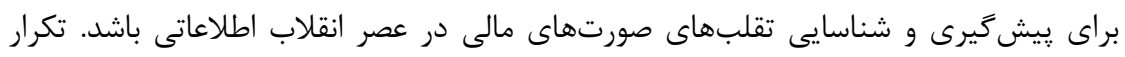

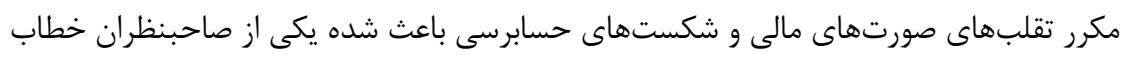

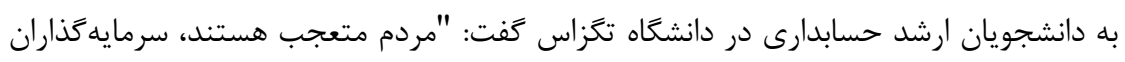

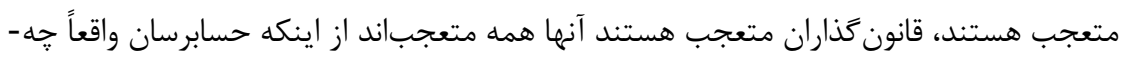

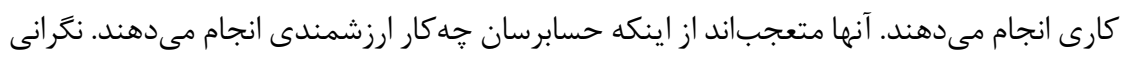

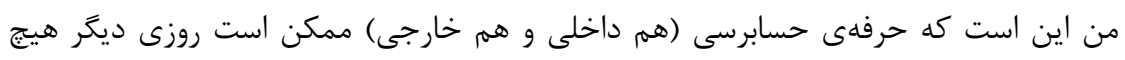

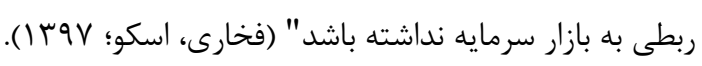

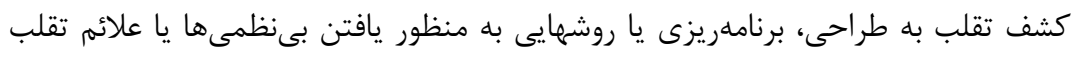

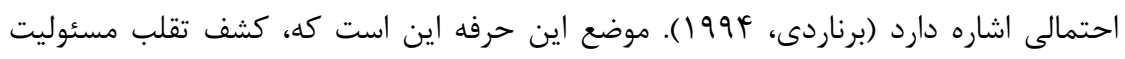

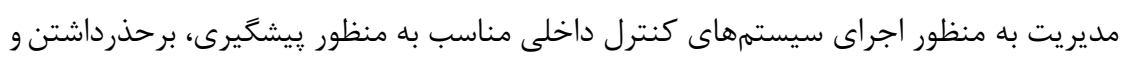

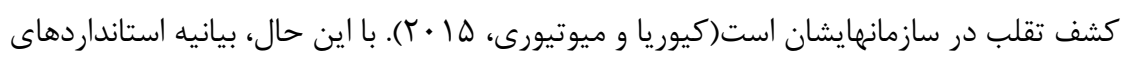

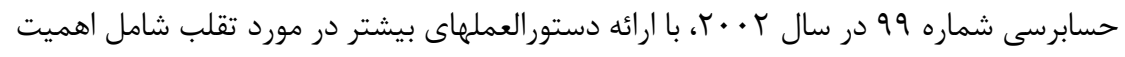

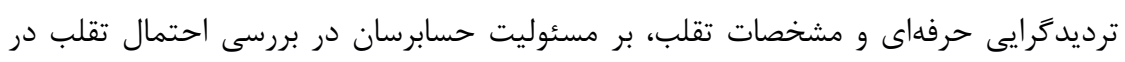

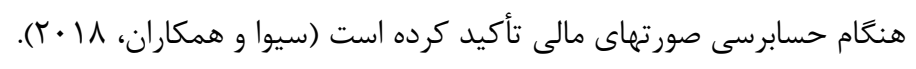

ه توانايى كشف تقلب

شكاف انتظارات بوجود آمده در رابطه با وظيفه حسابرسان در قبال كشف تقلب و يمانشخيرى

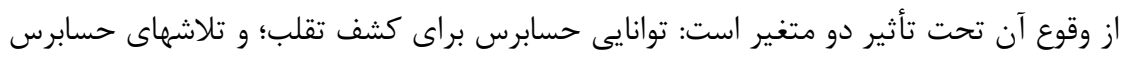

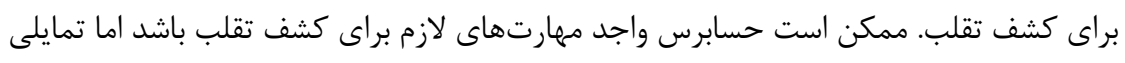

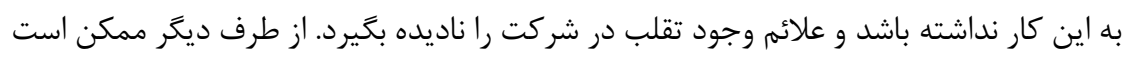

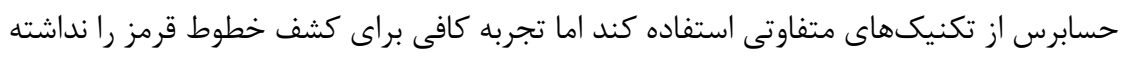

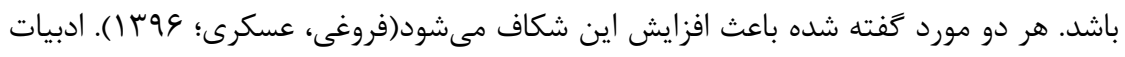

${ }^{1}$ Fraud Auditing 
موجود كشف تقلب نشان مى دهد كه علائم تقلب را مى توان در سه دسته گسترده قرار دارد: الف-

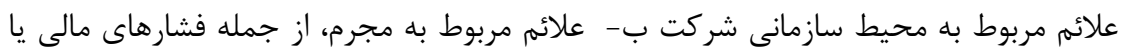
كارى، فرصت براى ارتكاب تقلب، و توجيه تقلب و ج- علائم مربوط به سوابق مالى و شيوهناى بـاي

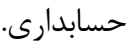

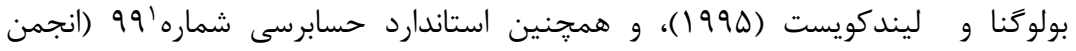

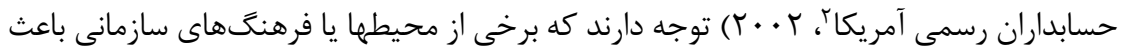

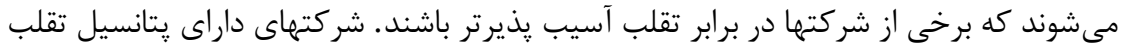

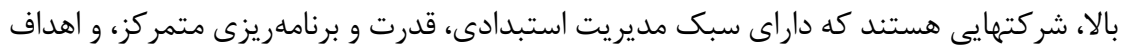

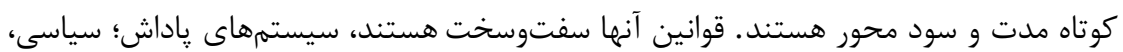

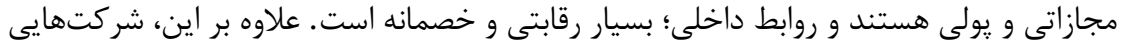

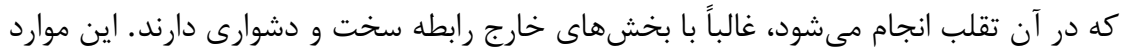

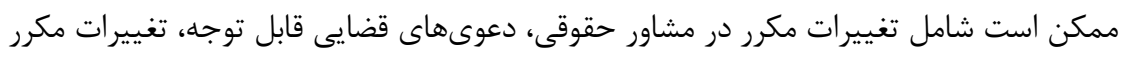

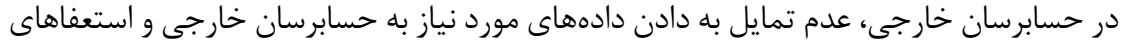
غيرقابل توضيح يا مكرر اعضاى هيئت مديره باشد. تقلبها اغلب بوسيله شناسايى مجرمان احتمالى قابل كشف هستند. علاوه بر اين، از آنجايى

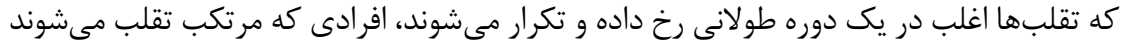

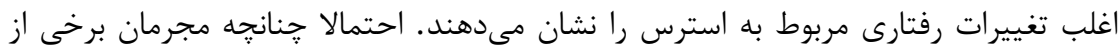

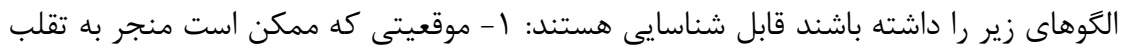

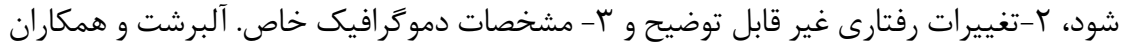

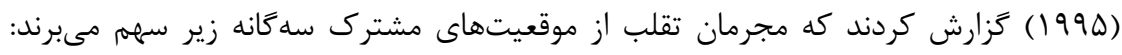

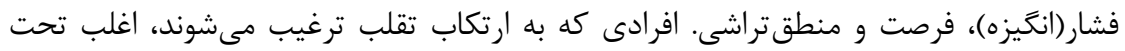

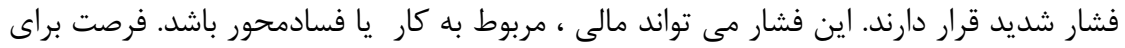

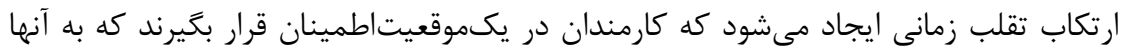

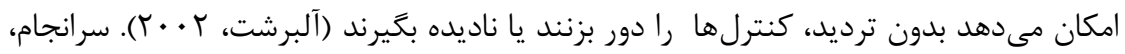

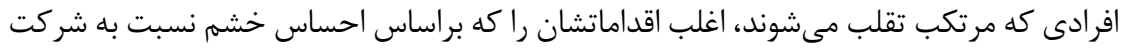

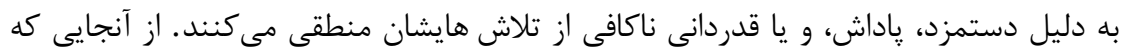

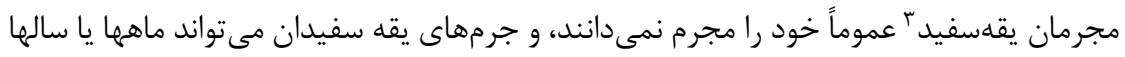

${ }^{1}$ SAS 99

${ }^{2}$ AICPA

${ }^{3}$ white-collar criminals 
ياشائى فشتالى و همكاران، بررسى تاثير اخلاق حرفه اى و فلسفه اخلاقى شخصى بر توانايى كثف تقلب... IV

ادامه يابد، مجرمين معمولاً شروع علائم استرس شديد را نشان مى دهند. به عنوان مثال، آلبرشت

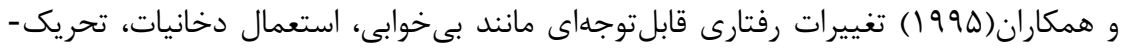

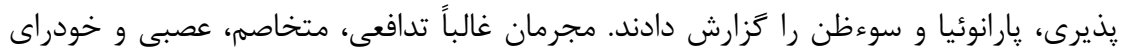

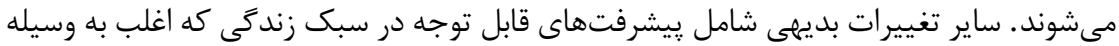

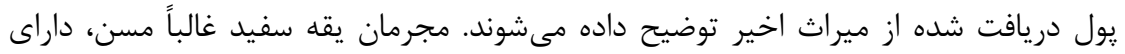

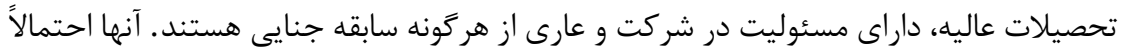

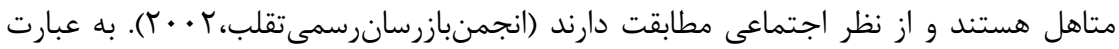

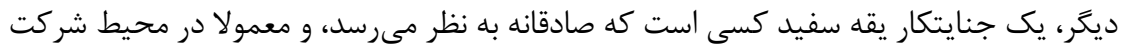

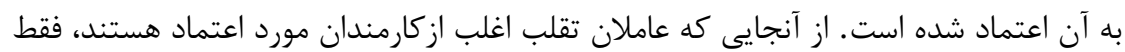

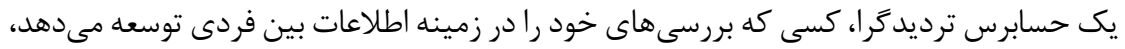

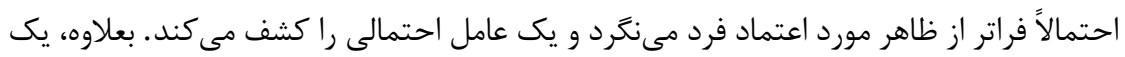

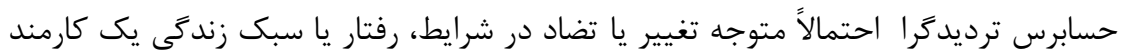

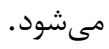
برخى از علائم تقلب در نحوه برخورد شركت با مدارك مالى منعكس معىشود. به عندوان مثان مثال،

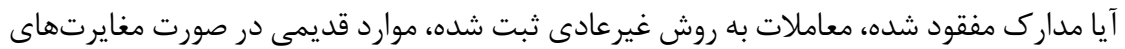
بانكى، يرداختهاى تكرارى و كنترلهاى داخلى ضعيف وجود دارد؟ به طور مشابه، ممكن است

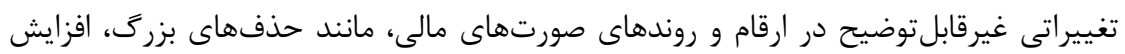

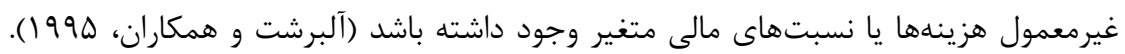
حسابرسانى كه جستجوى اطلاعات خود را افزايش مى دهند، بيشتر احتمال دارد كه در يروندهنهاى

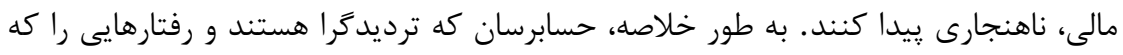

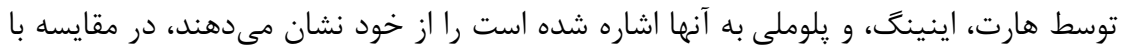

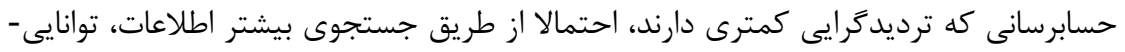

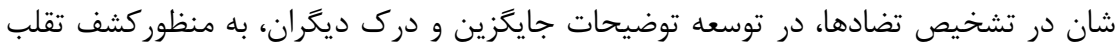

$$
\text { بيشتر است. }
$$
" اخلاق حرفهاى و توانايى كشف تقلب التبان

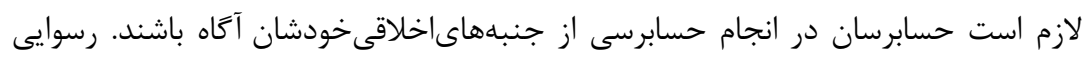

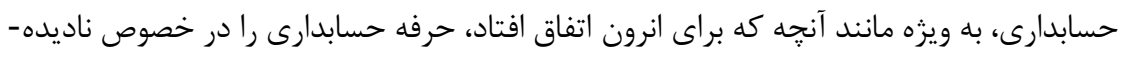

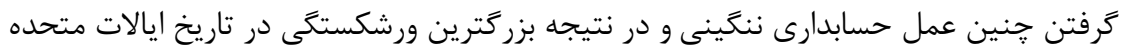

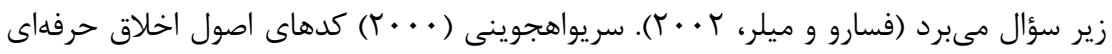

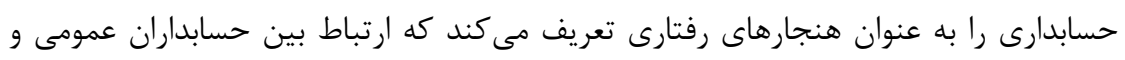


مشتريانشان را تنظيم مى كند. كدهاىاصولاخلاقى مملو از محتواهاى اخلاقى هستند كه اساساً

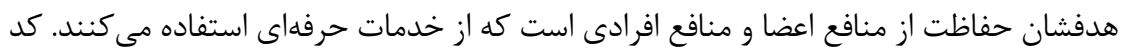

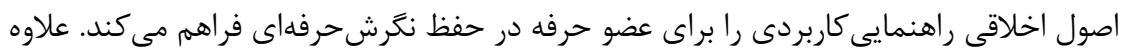

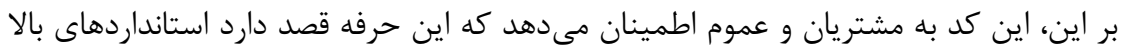

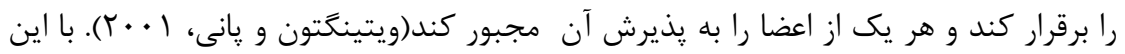

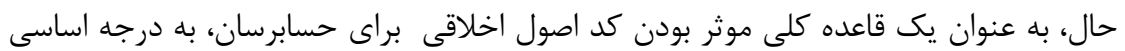

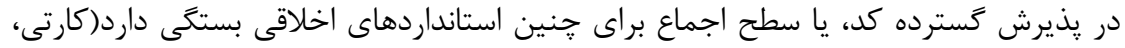

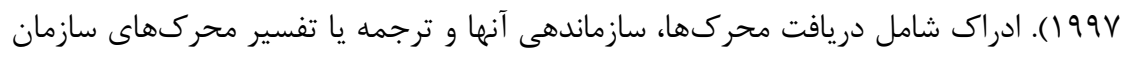

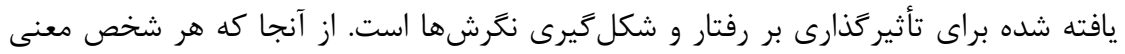

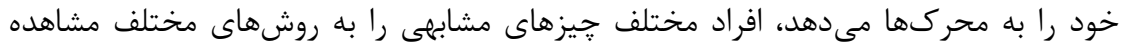

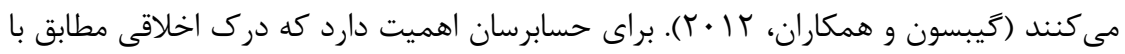

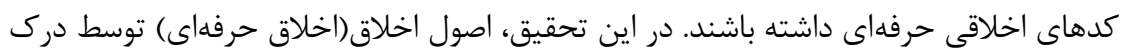

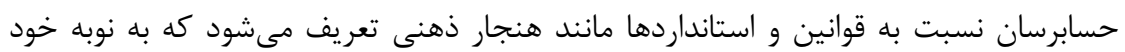

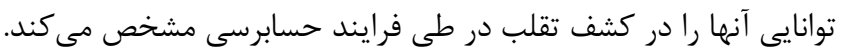

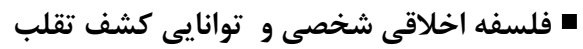

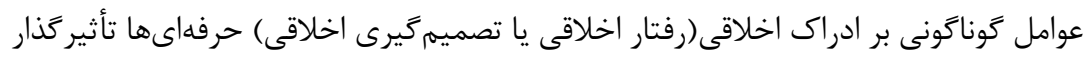

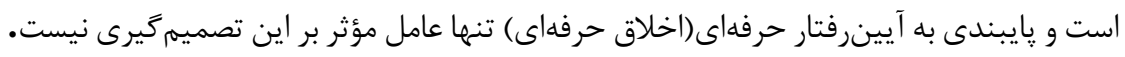

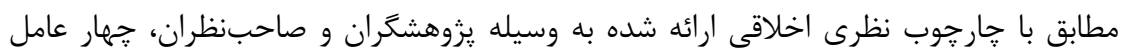

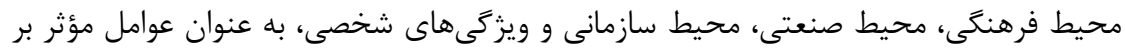

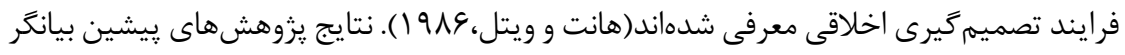

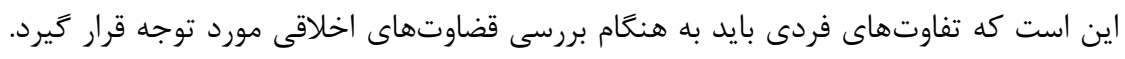

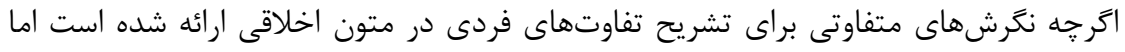

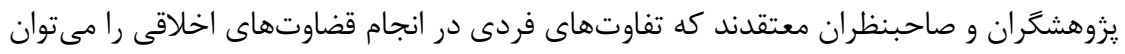

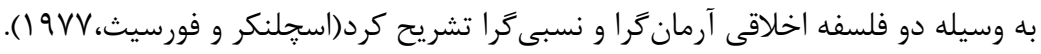

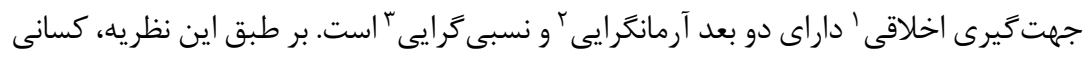

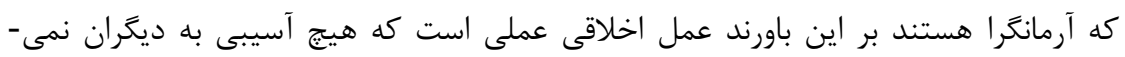

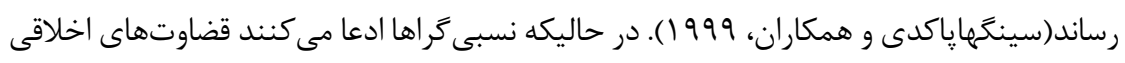

${ }^{1}$ ethical orientation

2 idealism

${ }^{3}$ relativism 
وابسته به شرابط هستند مانند فرهنگ، مكان و زمان. در حقيقت نسبى

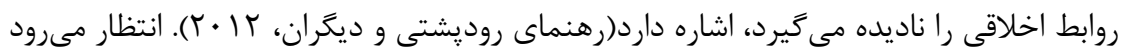

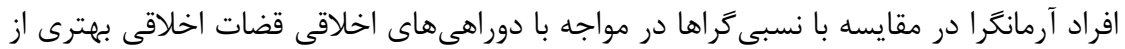

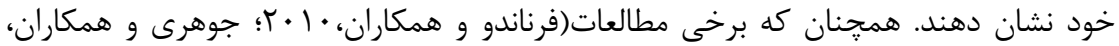

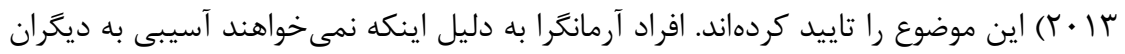

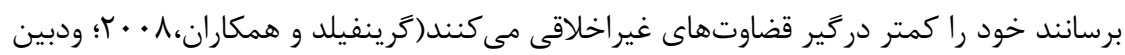

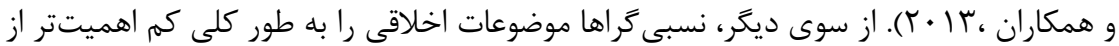
آرمانكًر اها مى دانند.

\section{ترديد حرفهاى و توانايى كشف تقلب}

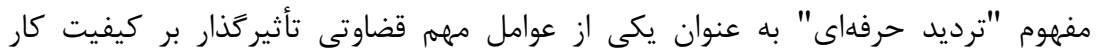

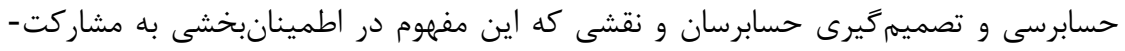

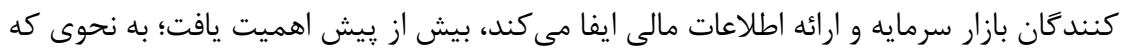

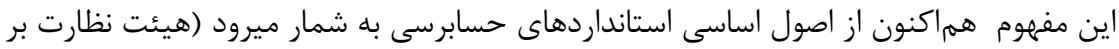

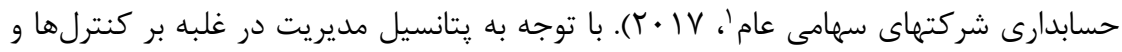

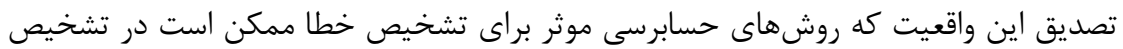

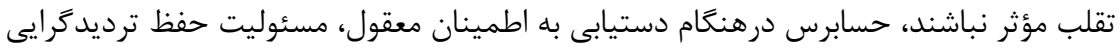

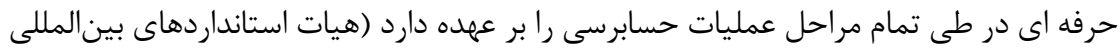

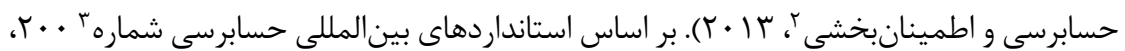
ترديد حرفهاى عبارت است از نكرشى كه متضمن وجود يك ذهن يرسشكر است(هشيارى نسبت

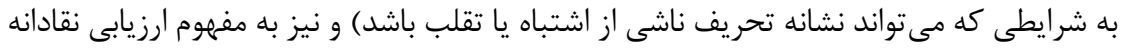
و دقيق شواهد حسابرسى است (هيات استانداردهاى بينالمللى حسابرسى و اطمينانبخشى،

حفظ ترديد حرفهاى در طى تمام مراحل فرايند حسابرسى براى حسابرس به منظور كاهش

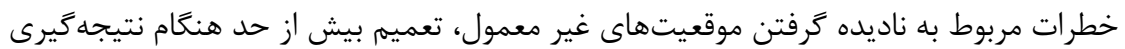

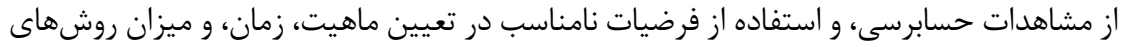

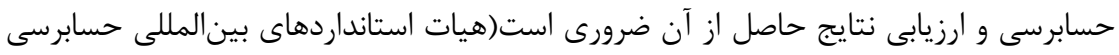

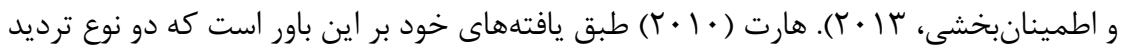

${ }^{1}$ Public Companies Accounting Oversight Board (PCAOB)

${ }^{2}$ The International Auditing and Assurance Standards Board (IAASB)

${ }^{3}$ International Standards of Auditing (ISA) 200 
حرفهاى به نام "ترديد شخصيتى يا ذاتى '" و " ترديد حالت ז" وجود دارد. وى ترديد شخصيتى را ماهيت ذاتا شكاكانه يك فرد معرفى مى كند كه در طول زمان ثابت است و شش مولفه "ذهن

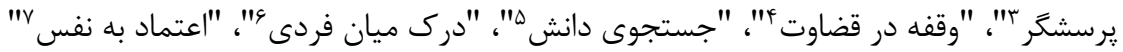
و "استقلال راى ^" را براى آن در نظر مى گيرد؛ اين در حالى است كه به باور او ترديد حالت، ترديدى موقعيتى است كه مى تواند بسته به ميزان درك فرد از يك موقعيت مشخص، افزايش يا كاهش يابد. سه مولفه نخست شخصيتى مرتبط با ترديد حرفهاى(ذهن يرسشخر، وقفه در قضاوت

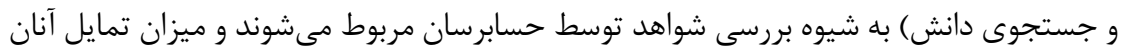

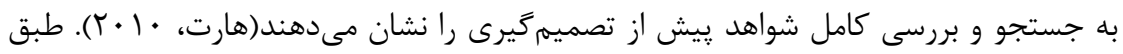
بيانيه شماره 99 استانداردهاى حسابرسى آمريكا، مولفه شخصيتى جهارم(دركى ميانفردى) نياز به جنبههاى انسانى حسابرسى در هنگام ارزيابى شواهد را تبيين مىنمايند(انجمن حسابداران

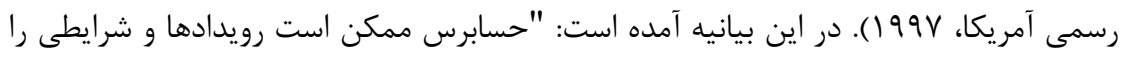

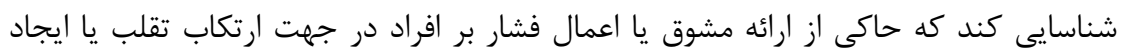
فرصت براى ارتكاب تقلب، يا ايجاد نكرش و برهانسازى در جهت توجيه اعمال متقلبانه باشد".

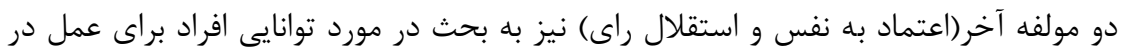
برابر اطلاعاتى كه كسب مىشود مى يردازند(هارت • ( • (؟).

ترديد حرفهاى هم براى حسابرسان داخلى و هم براى حسابرسان مستقل مهم است. بررسى

رفتار حسابرسان و جگگونكى تاثير ترديدگرايى بر مهارتهاى كشف تقلب يكى مولفه حياتى از محافظت در برابر قصور حسابرسى آتى است. اگر حسابرسان ترديدگرايى بيشترى اعتى اعمال نمايند به شناسايى انحراف در فرآيند حسابرسى كمك قابل توجهى مىشود. بنابراين ترديدگرايى در حسابرسى حياتى است(يونمون، سو (199).

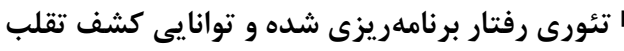
تئورى رفتار مورد استفاده در اين تحقيق تئورى رفتار برنامهريزى شده است. نخستين بار

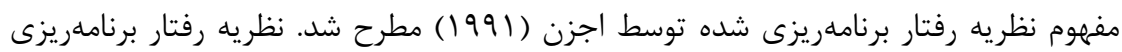

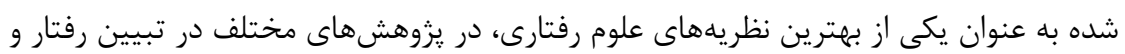

1 Trait Skepticism

${ }^{2}$ State Skepticism

${ }^{3}$ Questioning Mind

${ }^{4}$ Suspension of Judgment

${ }^{5}$ Search for Knowledge

${ }^{6}$ Interpersonal Understanding

${ }^{7}$ Self-esteem

${ }^{8}$ Autonomy 
ياشائى فشتالى و همكاران، بررسى تاثير اخلاق حرفه اى و فلسفه اخلاقى شخصى بر توانايى كثف تقلب...ابس

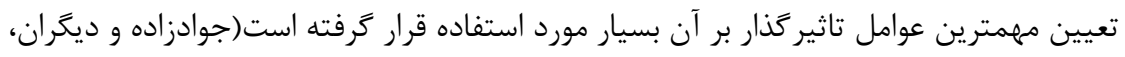

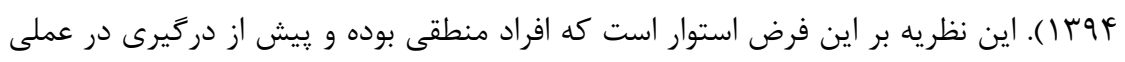

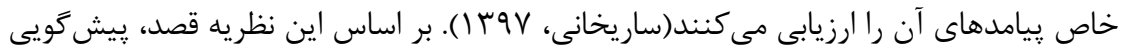

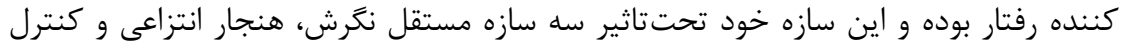

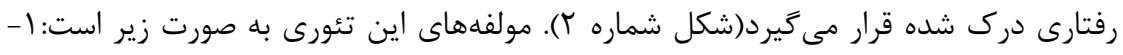

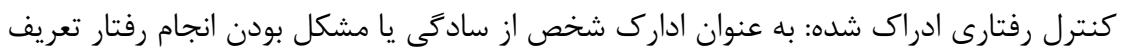

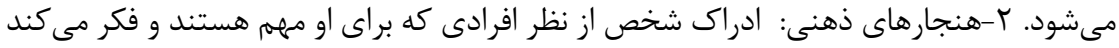

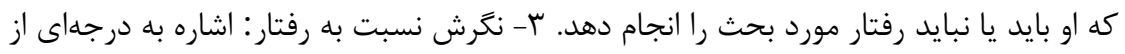

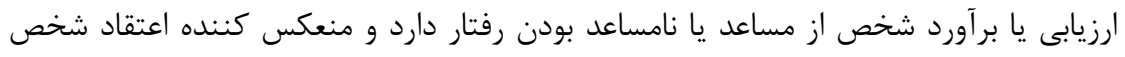

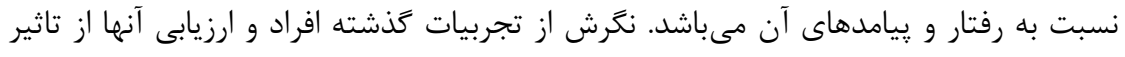

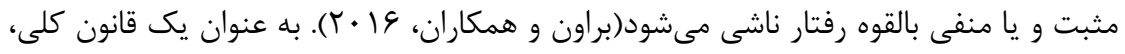

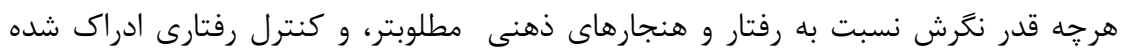

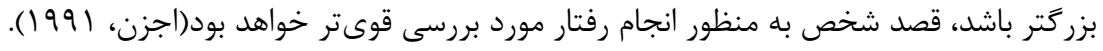

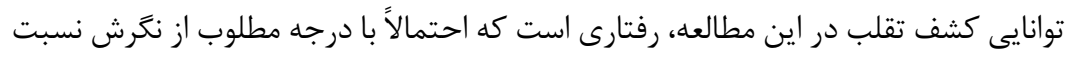

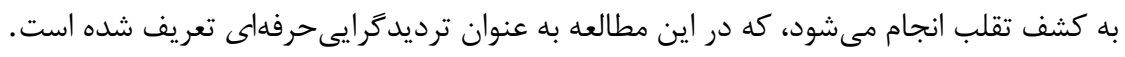

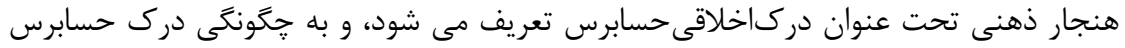

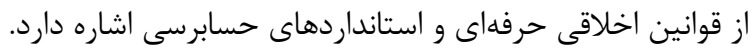

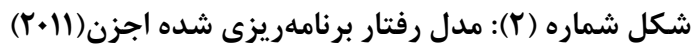

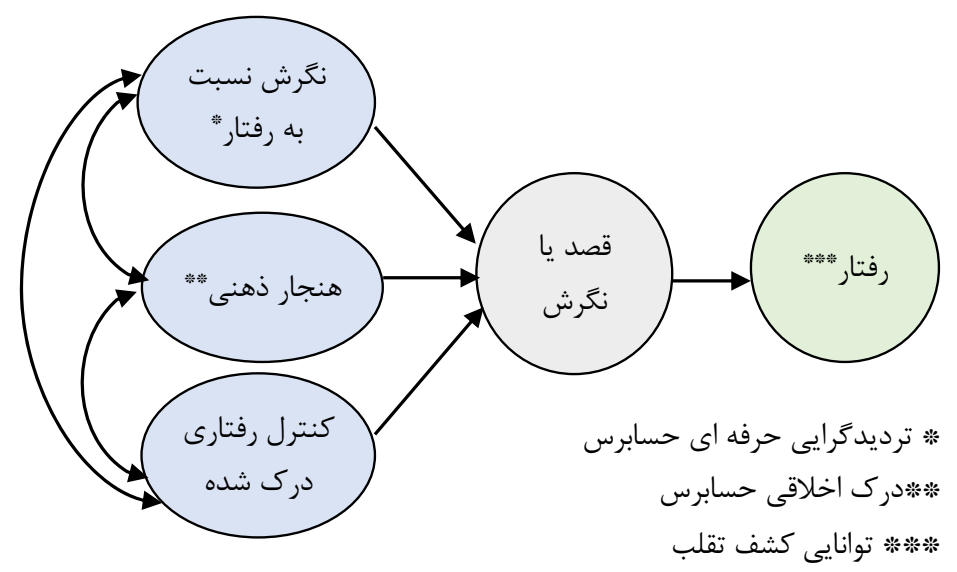


${ }^{1}$ Individual's moral philosophy 
ياشائى فشتالى و همكاران، بررسى تاثير اخلاق حرفه اى و فلسفه اخلاقى شخصى بر توانايى كثف تقلب... سبr

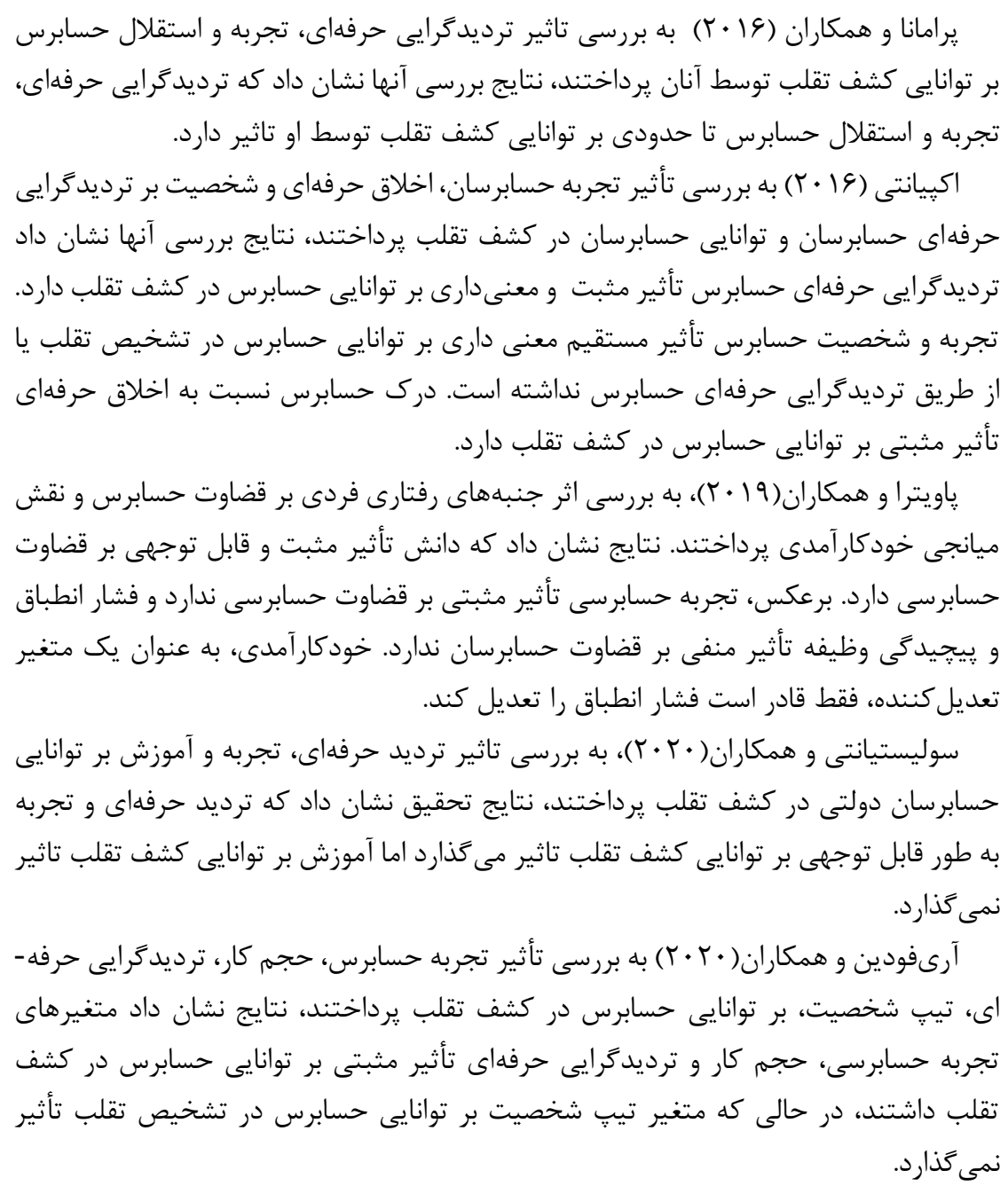

در ميان يزوهشهاى داخلى يزوهشى مشاهده نشد كه به طور خاص توانايى كشف تقلب را

مورد بررسى قرار داده باشد.

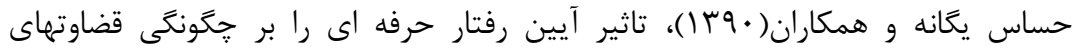

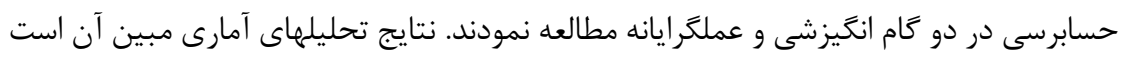

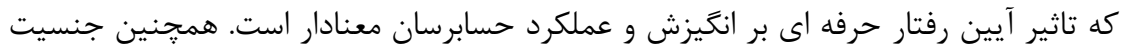

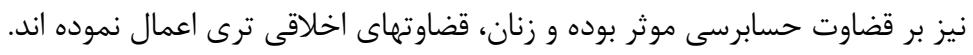




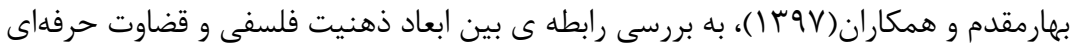

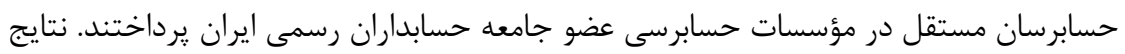

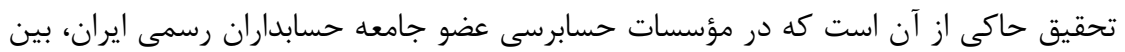
سه بعد ذهنيت فلسفى و قضاوت حرفهاى رابطه مثبت و معنادارى وجود دارد؛ اما بيشترين تأثير إنير

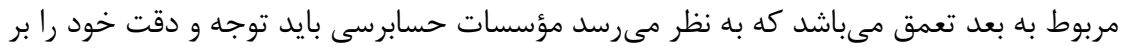

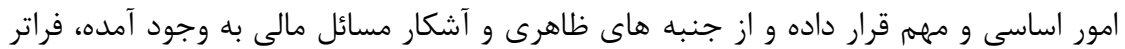

انصارى و همكاران(91 (I))، به بررسى رابطه ميان ترديد حرفهاى، سطح اطمينان و قضاوتها

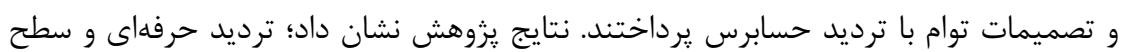

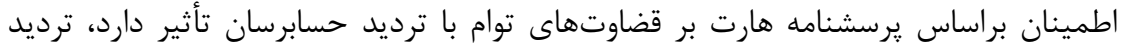
حرفهاى و سطح اطمينان براساس برسشنامه نئو بر قضاوتهاى توام بار تران برديد ترديد حسابرسان تأثير

حسينى و همكاران(99 1)، به بررسى تاثير ابعاد فرهنكى و مولفههاى رفتارى بر ترديد

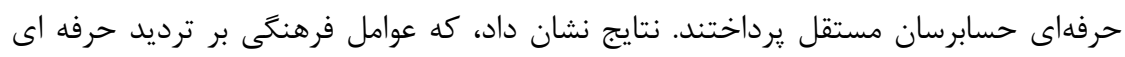

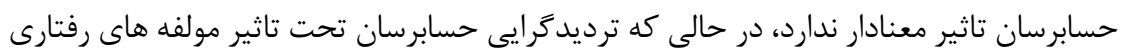

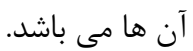
على يناه(99\%()، به بررسى ميزان تحصيلات حسابرسان بر استرس حسابرس و كيفيت

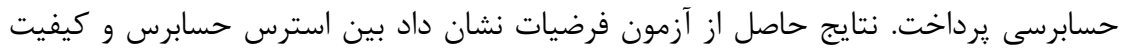

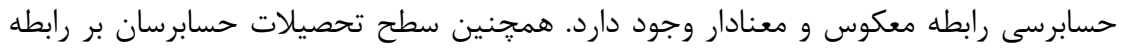
بين استرس حسابرس و كيفيت حسابرسى تاثير كذار است.

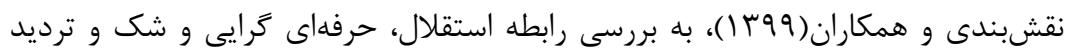
حرفهاى با كيفيت حسابرسى يرداختند، نتايج نشان داد؛ بين متغيرهاى استقلال، حرفهاى كرايى ترايى و شك و ترديد حرفهاى با كيفيت حسابرسى رابطه معنى دارى وجود دارداردان.

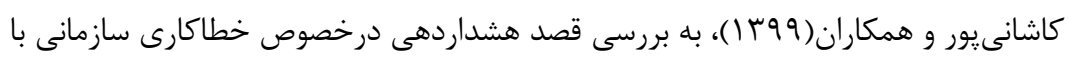

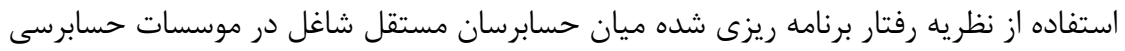

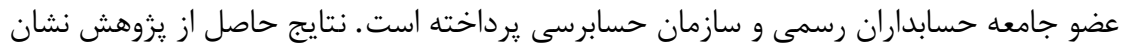

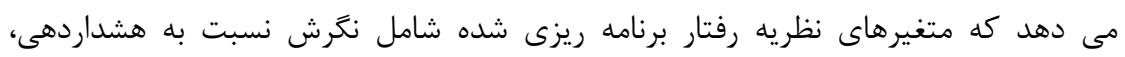

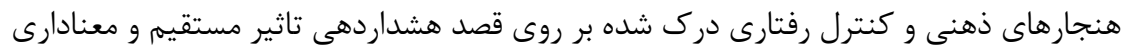

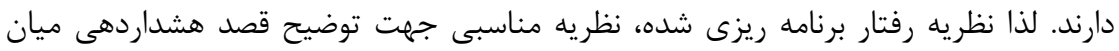
حسابرسان مستقل مى باشد. 


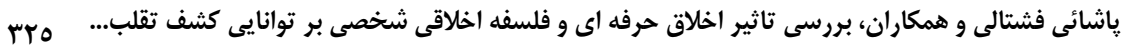

بنى مهد و همكاران( أ (1)، به بررسى رابطه جهت كيرى ارزشى، عواطف مثبت و درك از

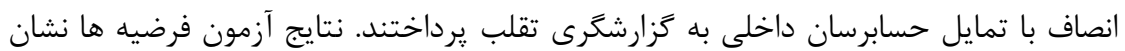

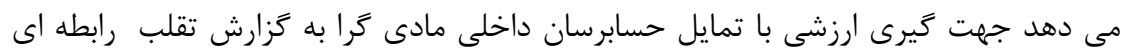

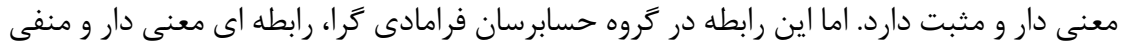

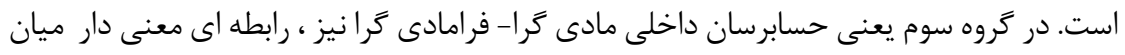
جهت كيرى ارزشى و تمايل به كزارش تقلب وجود ندان داردارد

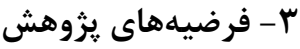

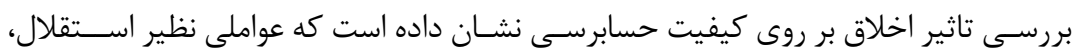
بى طرفى، تعهد حسابرس در اخلاق حرفهاى بر كيفيت حسابرسى اثر مثبت و معنادادارى

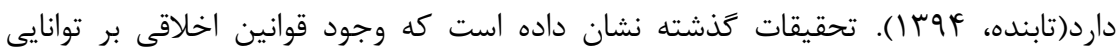

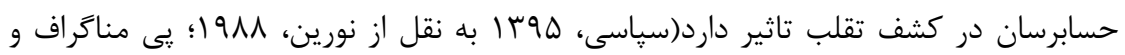

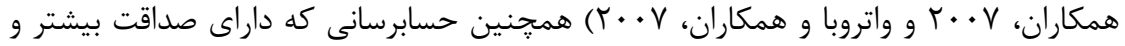

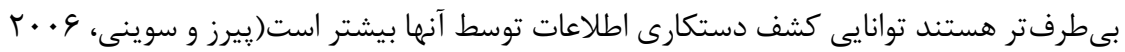

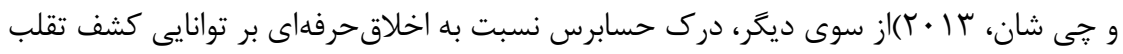

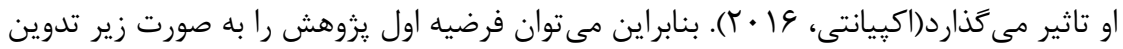

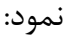

فرضيه اول: اخلاق حرفهاى بر توانايى كشف تقلب حسابرس خارجى تاثير مثبت دارد.

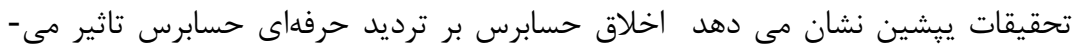

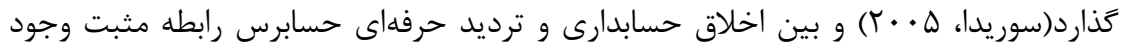

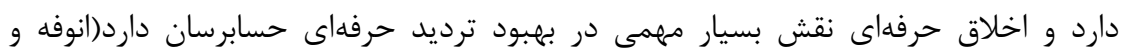

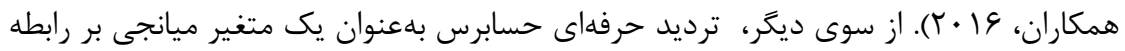

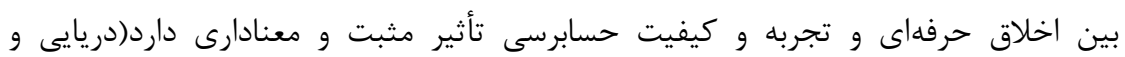

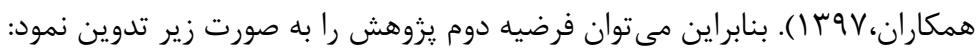

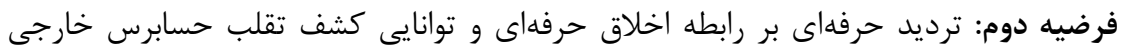
تاثير خذار است.

برخى مطالعات نشان مىدهند جهت

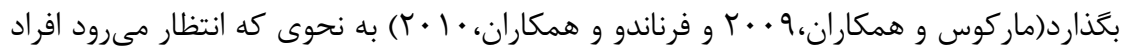
نسبى

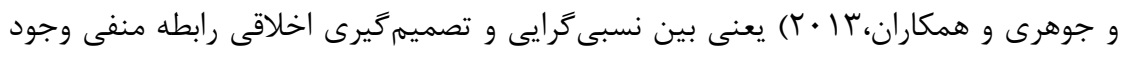




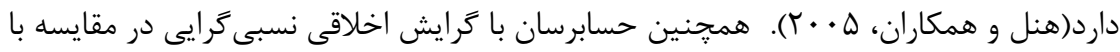

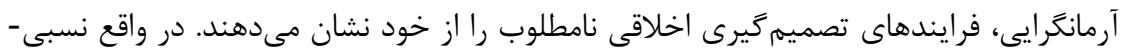

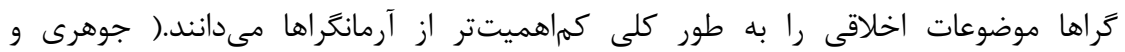

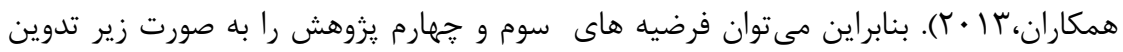
فرضيه سوم: جهت گيرى اخلاقى آرمان كرايى بر توانايى كشف تقلب حسابرس خارجى تاثير مثبت فرضيه جهارم: جهت منفى دارد. نتايج يزوهشهاى كذشته نشان مى دهد كه ترديد حرفهاى حسابرس بهعنوان يك متغير

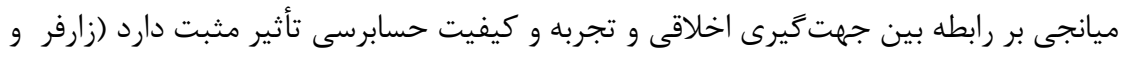

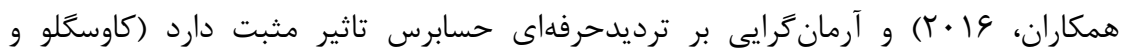

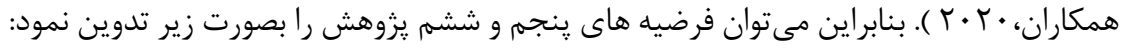

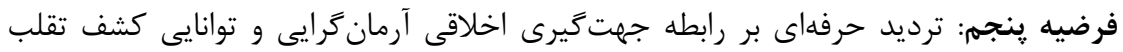

$$
\text { حسابرس خارجى تاثير كذار است. }
$$

فرضيه ششم: ترديد حرفهاى بر رابطه جهت حسابرس خارجى تاثير كذار است.

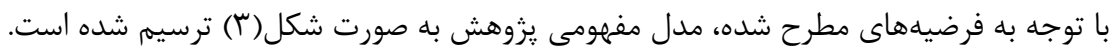

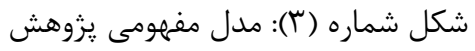

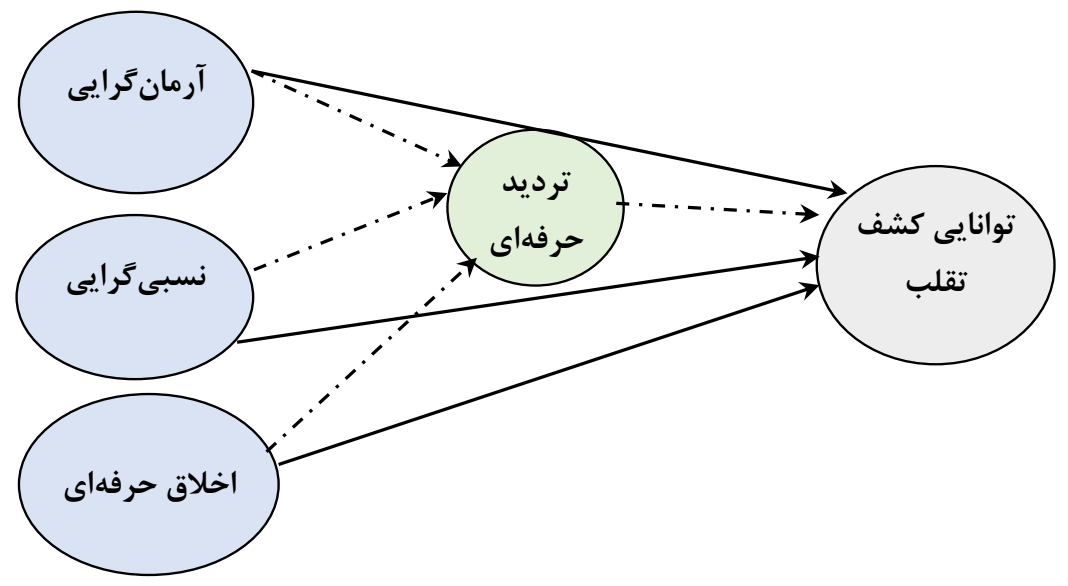


ياشائى فشتالى و همكاران، بررسى تاثير اخلاق حرفه اى و فلسفه اخلاقى شخصى بر توانايى كثف تقلب...

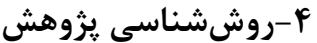

يزوهش حاضر از نوع تحقيقات رفتارى است. از ديدكاه هدف، كاربردى و از نظر ماهيت و

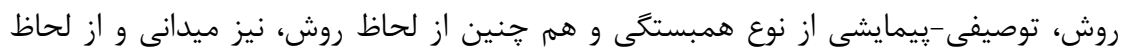

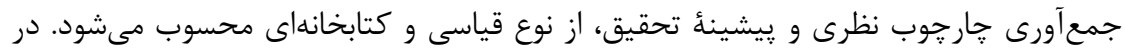

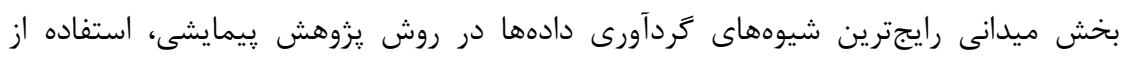

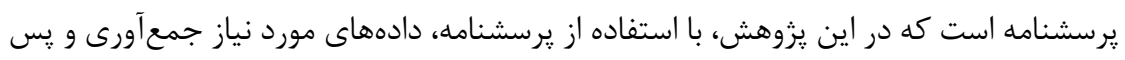

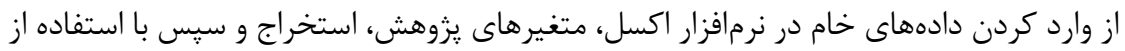

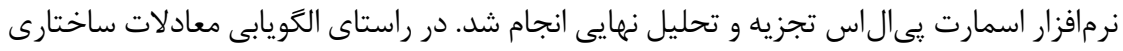

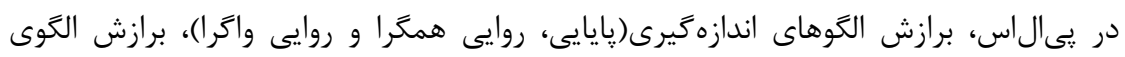

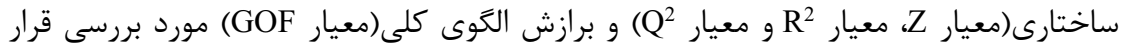

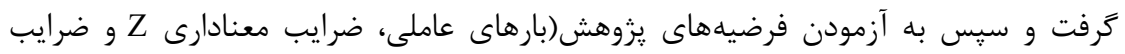

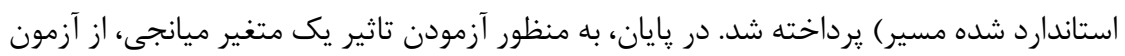
سوبل استفاده شد.

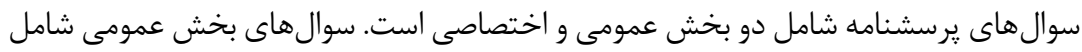

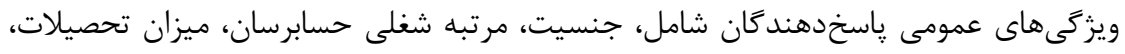

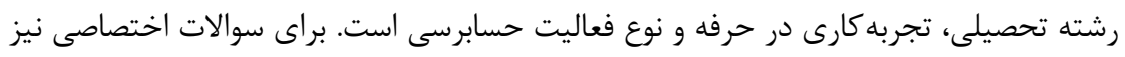

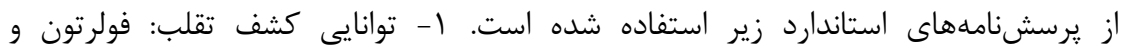

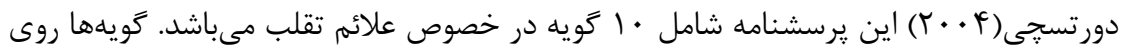

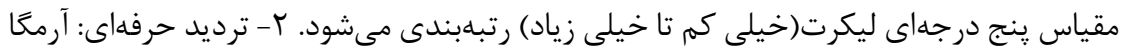

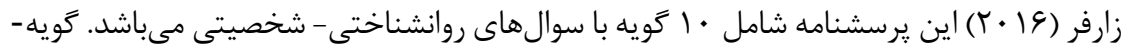

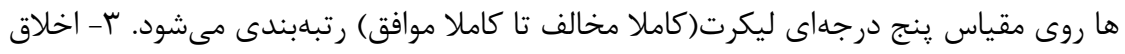

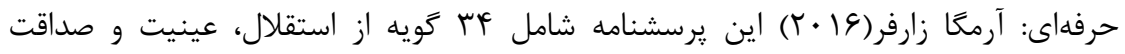

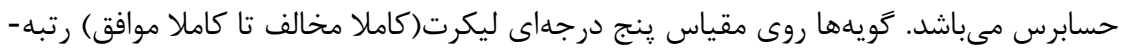

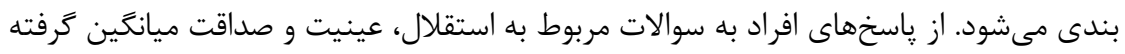

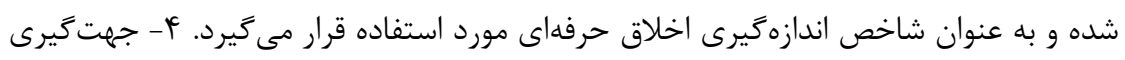

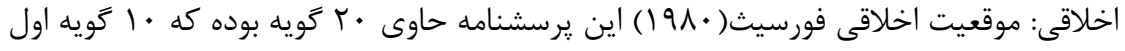

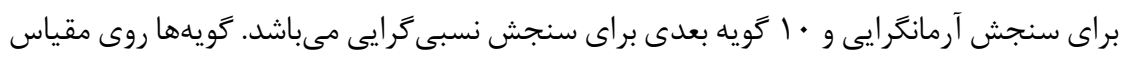

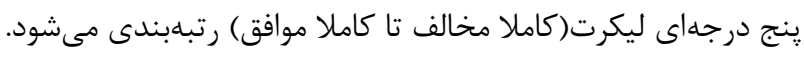


با توجه به مدل مفهومى يزوهش در شكل(ه)، متغير وابسته، توانايى كشف تقلب؛ متغير

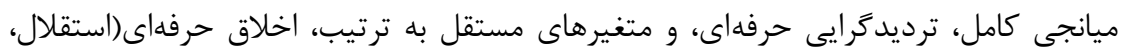

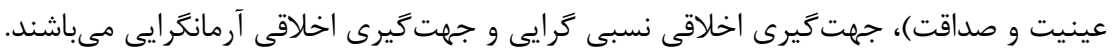

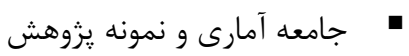

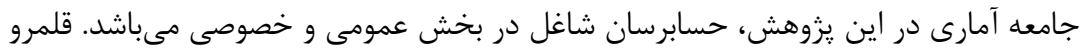

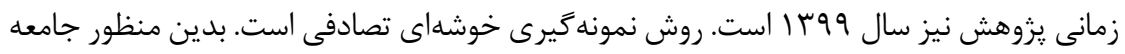

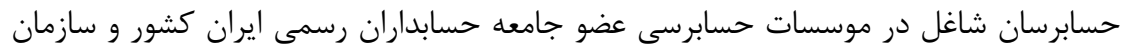

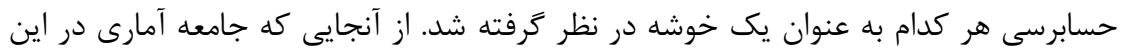

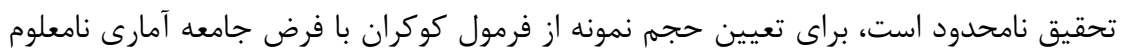
$n=\frac{\left(Z_{\frac{\alpha}{2}}\right)^{2} p q}{d^{2}}$

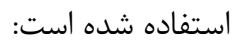

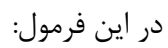
$n=0.1$

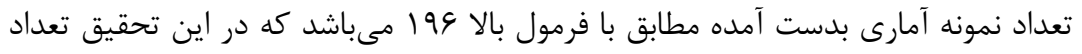

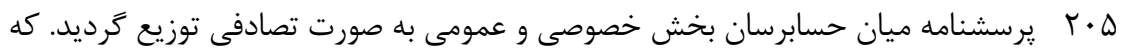

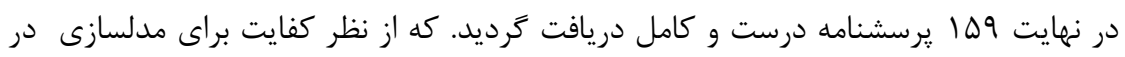
PLS

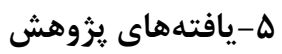

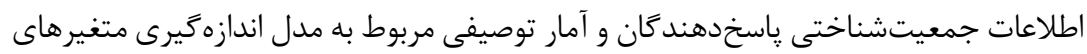
يزوهش در جدول(1) و (r) ارائه شده است.

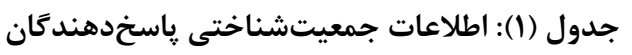

\begin{tabular}{|c|c|c|c|}
\hline درصد & آمار & \multicolumn{2}{|c|}{ اطلاعات جمعيتشناختى } \\
\hline & 109 & & مشاركت كنندكان \\
\hline$r f$ & $\Delta F$ & زن & \multirow{2}{*}{ جنسيت } \\
\hline 94 & $1 \cdot 0$ & مرد & \\
\hline V..$\Delta$ & ir & كارشناسى & \multirow{3}{*}{ تحصيلات } \\
\hline$\Delta 1$ & $\wedge 1$ & كارشناسى ارشد & \\
\hline$f 1 . \Delta$ & 99 & دكترى & \\
\hline
\end{tabular}


ياشائى فشتالى و همكاران، برر سى تاثير اخلاق حرفه اى و فلسفه اخلاقى شخصى بر توانايى كثف تقلب... وبץ

\begin{tabular}{|c|c|c|c|}
\hline MT.l & 01 & كمك حسابرس & \multirow{5}{*}{ سمت } \\
\hline rA.r & id & حسابرس & \\
\hline $9.4^{1}$ & 10 & حسابرس ارشد & \\
\hline 11.9 & r. & مدير & \\
\hline $11 . r$ & 11 & شريك & \\
\hline
\end{tabular}

جدول (r): آمار توصيفى

\begin{tabular}{|c|c|c|c|c|c|}
\hline نسبى گرايى & آرمانگرايى & اخلاق حرفهاى & ترديد حرفهاى & توانايى كشف تقلب & شرح \\
\hline$r \cdot \Lambda 1$ & $f \mid . \Delta F$ & IT.AV & FI. $1 F$ & $f \cdot .91$ & ميانگين \\
\hline ו & FT & 11.99 & ET & ET & ميانه \\
\hline ५.१९ & f.VA & $.11 \mathrm{~F}$ & $r .90$ & r.१V & انحر افمعيار \\
\hline ra & $r$ r. & $11 . r 1$ & MF & ra & كمترين \\
\hline$\forall \wedge$ & fF & If.rv & $4 q$ & f\& & بيشترين \\
\hline
\end{tabular}

برازش مدلهاى اندازهَيرى

در برازش مدل اندازهخيرى از سه معيار يايايى، روايى همخرا و روايى واگرا استفاده مىشود.

يايايى نيز از دو طريق، سنجش بارهاى عاملى و يايايى تركيبى مورد بررسى قرار مى ميى ميرد. مقدار

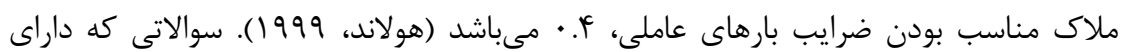
بارهاى عاملى كمتر از f. • مى باشد بايد از مدل حذف كرد. در صورتى كه ضريب يايايى تركيبى

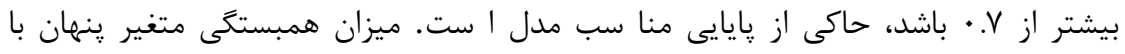

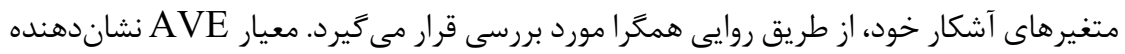
روايى همخرا است. جنانجه مقدار AVE بيشتر از ه. • باشد، روايى همخرا در سطح مناسبى است.

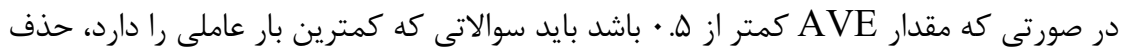

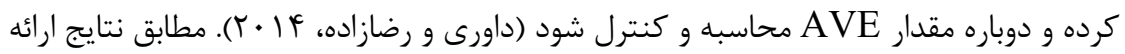
شده در جدول (ب)، بار عاملى سوالات، مقدار AVE و ضريب پايايى تركيبى هر متغير ينهان تحقيق در سطح مناسب و مورد تاييدى قرار دارد در نتيجه متغيرها از روايى همخراى مطلوبى برخوردار هستند. 
دو فصلنامه حسابدارى ارزشى و رفتارى، سال ينجم، شماره دهم، پإييز و زمستان و9جا

•r"

\begin{tabular}{|c|c|c|c|c|}
\hline 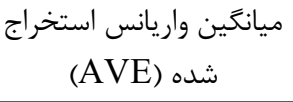 & ضريب يايايى & بار عاملى & شماره سوال & متغير \\
\hline \multirow{4}{*}{ } & \multirow{4}{*}{$\cdot .119$} & سזג. & rF & \multirow{4}{*}{ توانايى كشف تقلب } \\
\hline & &.$V I f$ & ra & \\
\hline & & .849 & is & \\
\hline & & - . $r q$ & Fr & \\
\hline \multirow{3}{*}{$\cdot \Delta \cdot r$} & \multirow{3}{*}{$\cdot V \Delta \cdot$} & س & r. & \multirow{3}{*}{ ترديد گرايى حرفهاى } \\
\hline & &. .999 & I & \\
\hline & &.$\Delta K I$ & سب & \\
\hline \multirow{3}{*}{$\cdot .9 r \cdot$} & \multirow{3}{*}{$\cdot .9 V T$} & $.9 \Delta r$ & TI & \multirow{3}{*}{ اخلاق حرفه اى } \\
\hline & & $\cdot .999$ & tr & \\
\hline & & $\cdot .9 \Delta \Delta$ & r & \\
\hline \multirow{6}{*}{ - $\Delta T q$} & \multirow{6}{*}{$\cdot .199$} & -.$\Delta V V$ & If & \multirow{6}{*}{ جهت كيرى اخلاقى } \\
\hline & & $\cdot . \vee \wedge 9$ & 19 & \\
\hline & & $\cdot .114$ & IV & \\
\hline & &. $.8 \Lambda$. & 11 & \\
\hline & & · & 19 & \\
\hline & &. .991 & $r$. & \\
\hline \multirow{3}{*}{. $.9 F V$} & \multirow{3}{*}{. AFT } & . AfF & V & \multirow{3}{*}{ جهت گَيرى اخلاقى } \\
\hline & & $.91 \mathrm{f}$ & 9 & \\
\hline & & $.9 T \Delta$ & 1 . & \\
\hline
\end{tabular}

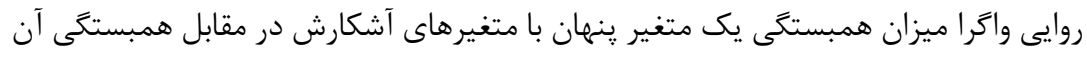

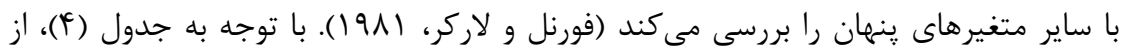

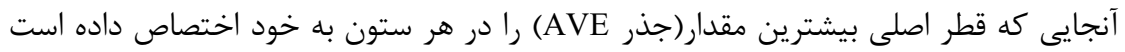

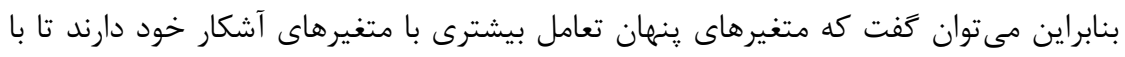

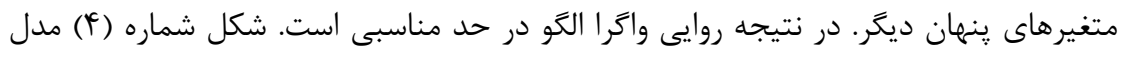

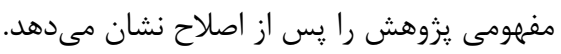


ياشائى فشتالى و همكاران، برر سى تاثير اخلاق حرفه اى و فلسفه اخلاقى شخصى بر توانايى كشف تقلب... ـ اسب

\begin{tabular}{|c|c|c|c|c|c|}
\hline \multicolumn{6}{|c|}{ جدول (F): ماتريس روايى واترا با روش فورنل و لاركر } \\
\hline نسبى گرايى & كشف تقانايى & ترديد حرفهاى & حرفهاى اخلاق & آرمانكرايى & 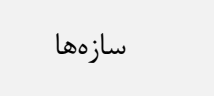 \\
\hline & & & & $\cdot \Lambda \cdot f$ & آرمانگرايى \\
\hline & & & $\cdot .909$ & $\cdot . \mathrm{Vr} \cdot$ & اخلاق حرفهاى \\
\hline & & $\cdot$.VAT & $\cdot . \vee \vee q$ & $\cdot .99 \cdot$ & ترديد حرفهاى \\
\hline & $\cdot . \vee \wedge \varsigma$ & $\cdot . \vee \vee \wedge$ & $\cdot . V V F$ & $\cdot .9 \Delta \Lambda$ & توانايى كشف تقلب \\
\hline$\cdot . V Y V$ & $-\cdot . q q$. & $-\cdot . \dot{F \wedge}$ & $-\cdot .49$ & 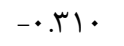 & نسبى گرايى \\
\hline
\end{tabular}

شكل(F): مدل مفهومى يزوهش يس از اصلاح به همراه ضرايب مسيرها و معنىدارى ضرايب

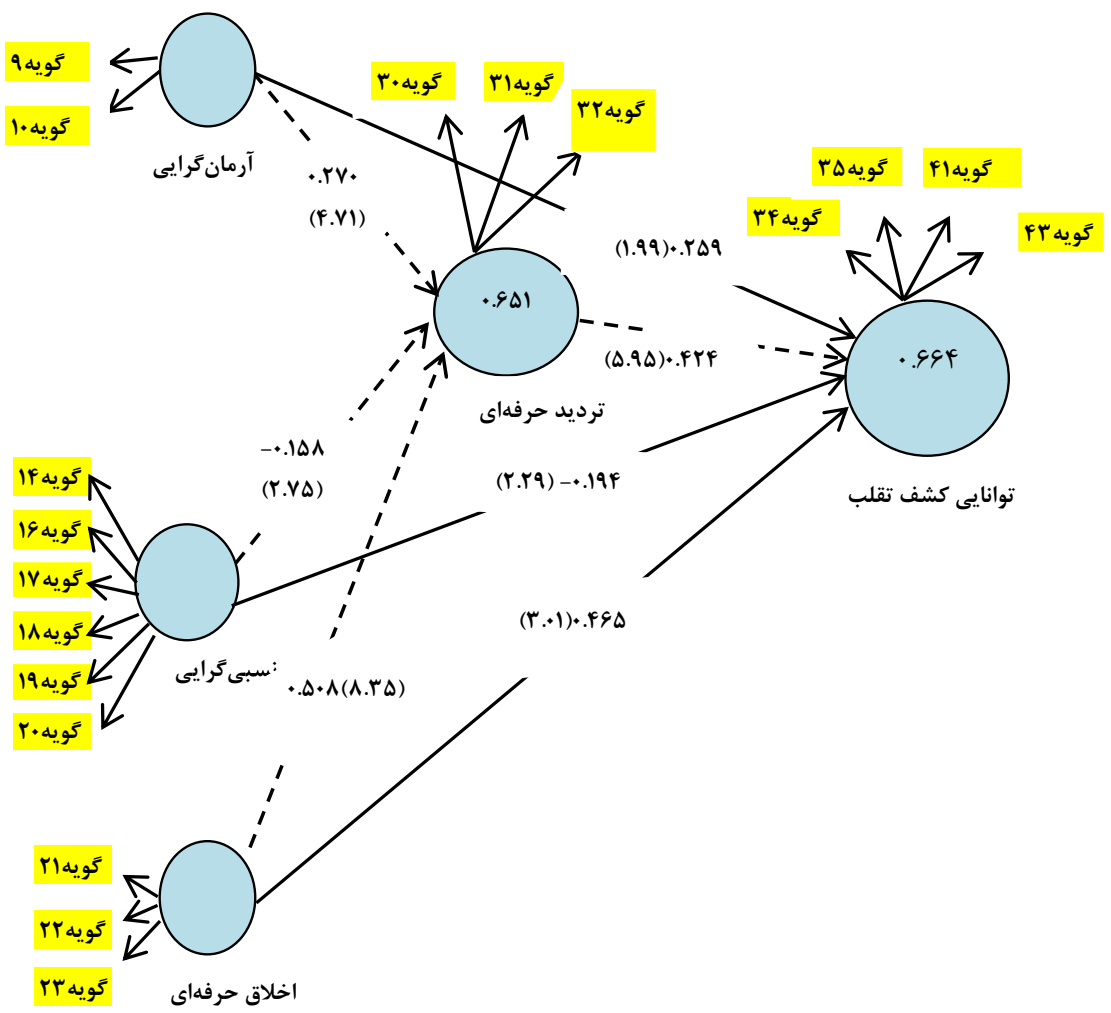




\section{برازش مدل ساختارى}

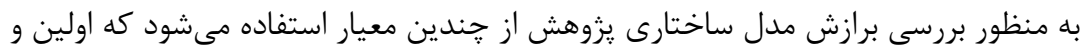

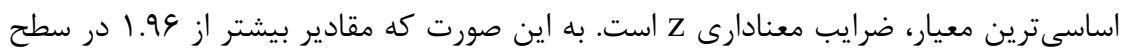

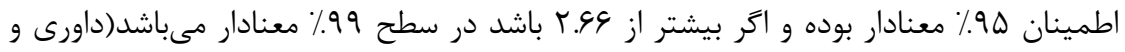

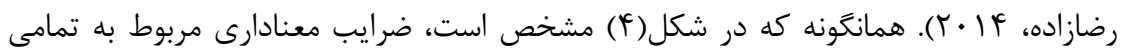

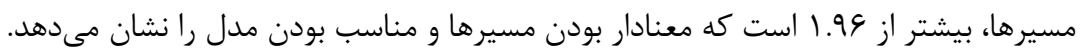

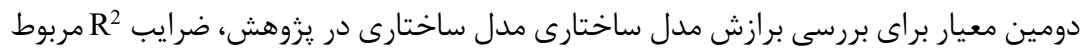

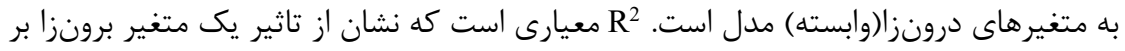

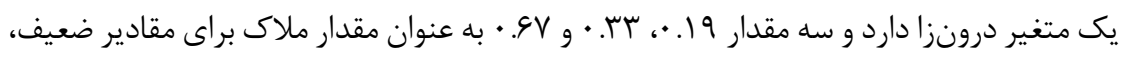

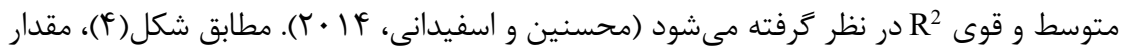

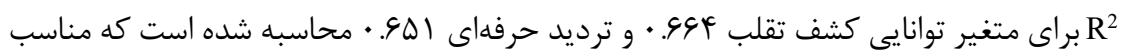
بودن برازش مدل ساختارى را تاييد مي كند.

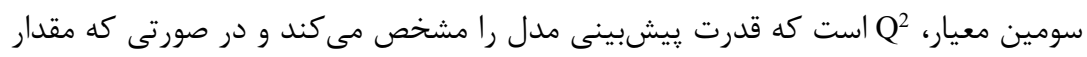

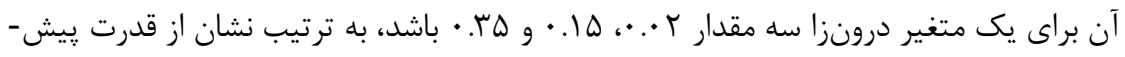

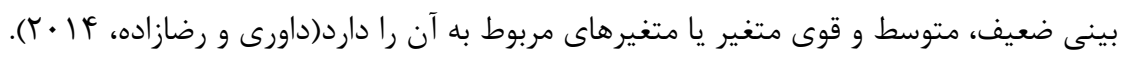

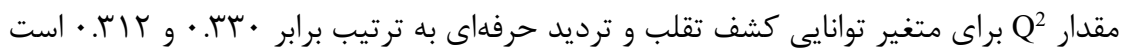
كه نشان دهنده قدرت قوى بيشبينى مدل مدل است برازش كلى مدل يس از اينكه برازش الكَوى اندازهيرى و الكَوى ساختارى تاييد شد، برازش كلى الكو با استفاده GOF $=\sqrt{\overline{\text { Communalities }} \times \overline{R^{2}}}$ از معيار GOF بررسى مىشود: مقدار

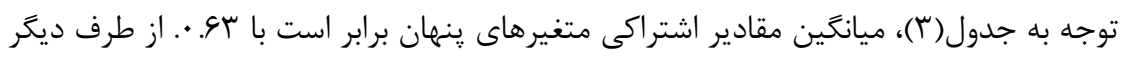

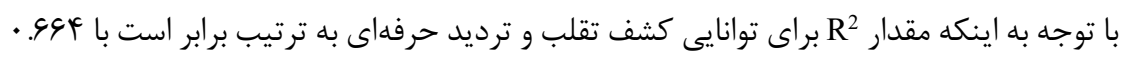
و آه ه •، مقدار

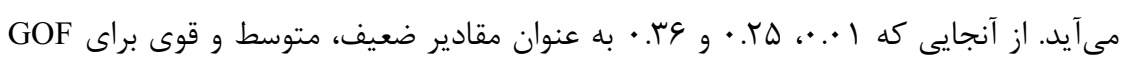

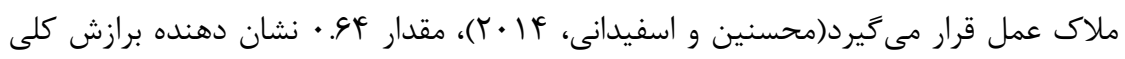

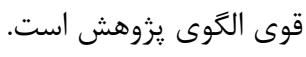


ياشائى فشتالى و همكاران، بررسى تاثير اخلاق حرفه اى و فلسفه اخلاقى شخصى بر توانايى كثف تقلب... سبس

آزمون فرضيه ها

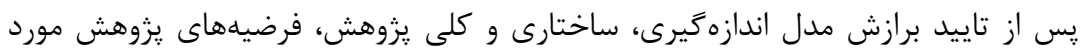

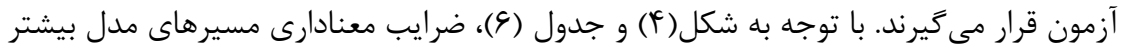

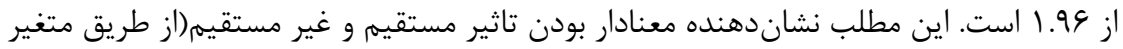

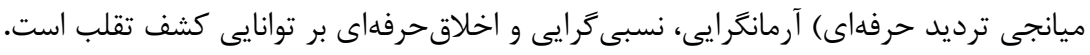
جدول(9): نتايج حاصل از آزمون فرضيههاى مستقيم

\begin{tabular}{|c|c|c|c|c|c|}
\hline نتيجه & ضريب تعيين & معنادارى & 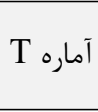 & ضريب & 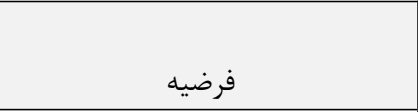 \\
\hline تاييد فرضيه & \multirow{3}{*}{.994} &..$\varphi V$ & 1.99 & $\cdot . r \Delta q$ & آرمانكر ايى ـ ـتوانايى كشف تقلب \\
\hline تاييد فرضيه & & $\cdot r \mu$ & r.rq &.- .194 & نسبى كرايى ـ توانيى كشف تقلب \\
\hline تاييد فرضيه & & $\cdot . r$ & $r .1$ & $\cdot .490$ & اخلاق حرفهاى ـ توانايى كشف تقلب \\
\hline
\end{tabular}

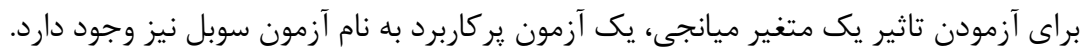

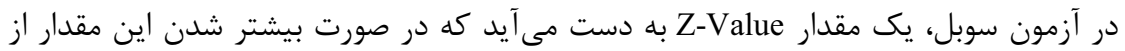

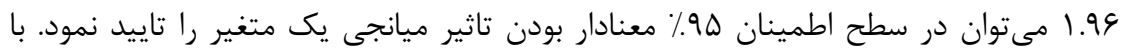

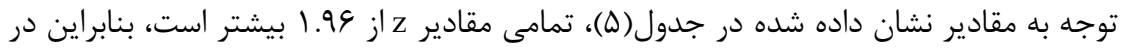

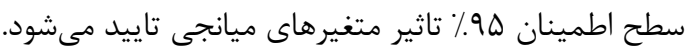

جدول(ه): مقادير z آزمون سوبل

\begin{tabular}{|c|c|}
\hline مقدار z آزمون سوبل & مسير \\
\hline r..99 & آرمانكرايى، ترديد حرفهاى، توانايى كشف تقلب \\
\hline r. . 9 & نسبى گرايى، ترديد حرفهاى ، توانايى كشف تقلب \\
\hline r.1ब & اخلاق حرفهاى، ترديد حرفهاى ، توانايى كشف تقلب \\
\hline
\end{tabular}

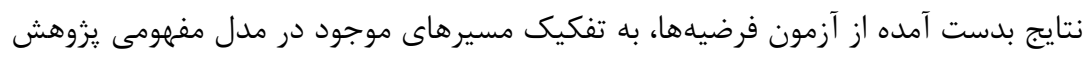

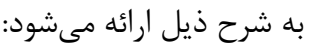

در آزمون فرضيه اول، مقدار ضريب مسير اخلاق حرفهاى بر توانايى كشف تقان آنلب حسابرس

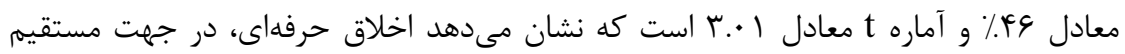

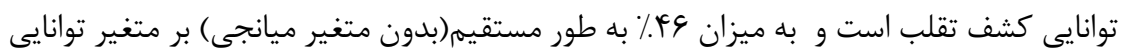

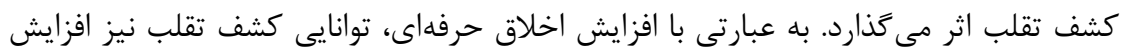
مىيابد. لذا فرضيه اول تاييد مىشود. 


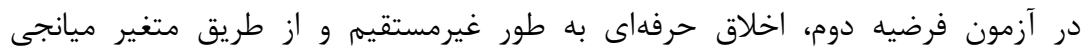

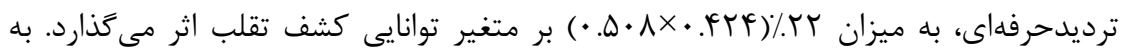

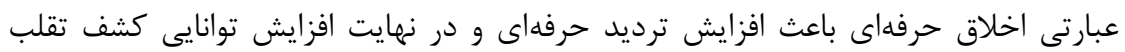

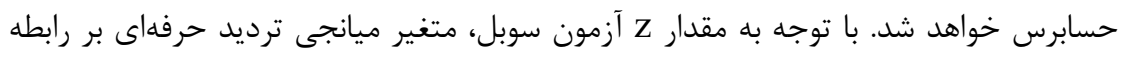

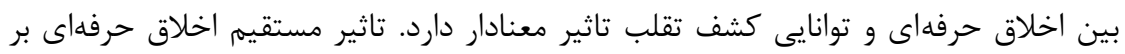

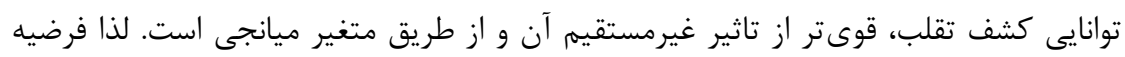
دوم تاييد مىشود.

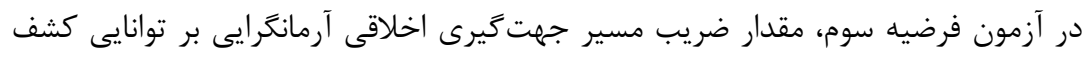

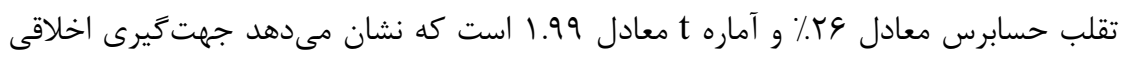

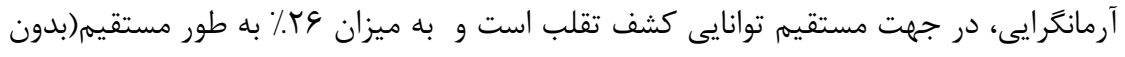

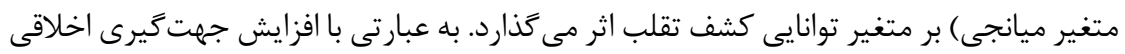

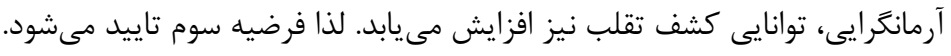

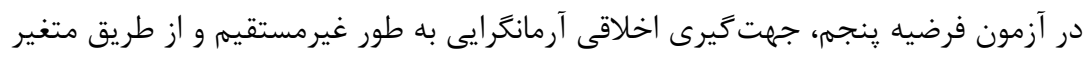

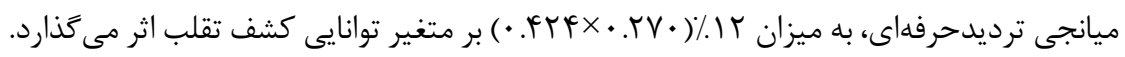

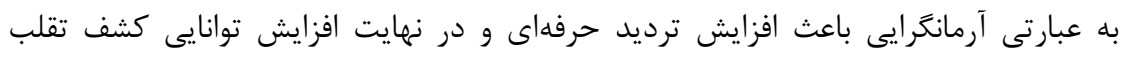

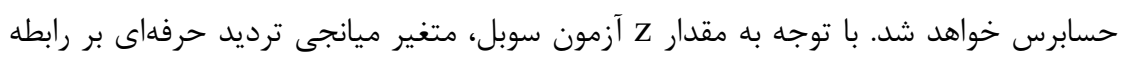

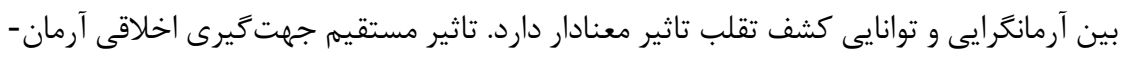

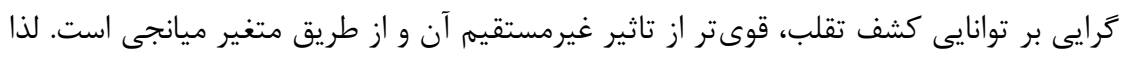
فرضيه ينجم تاييد مى شورد.

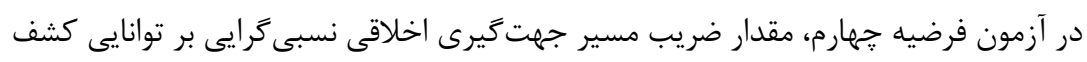

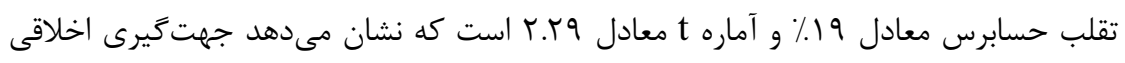

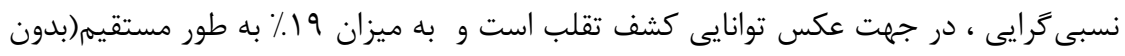

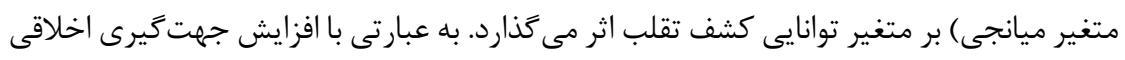

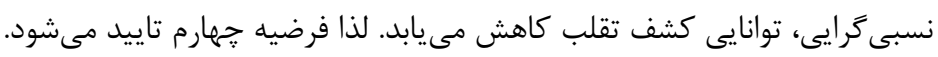

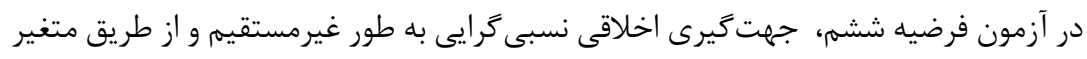

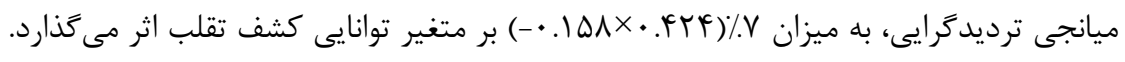
به عبارتى نسبى

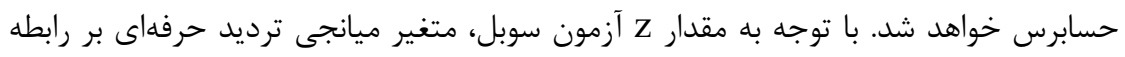
بين نسبى 
ياشائى فشتالى و همكاران، بررسى تاثير اخلاق حرفه اى و فلسفه اخلاقى شخصى بر توانايى كثف تقلب...هبس

نسبى كرايى بر توانايى كشف تقلب، قوىتر از تاثير غيرمستقيم آن و از طريق متغير ميانجى است. لذا فرضيه ششم تاييد مىشود.

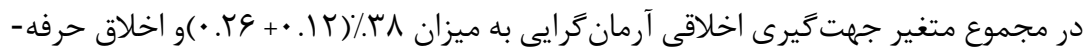

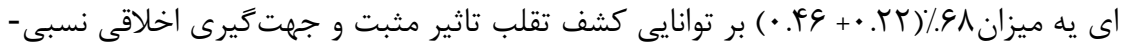

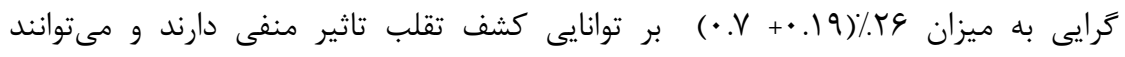

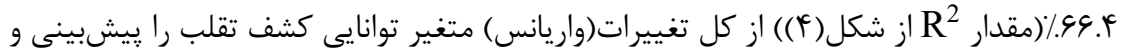
تبيين نمايند.

\section{9-نتيجه كيرى و بحث}

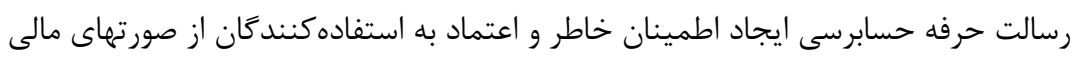

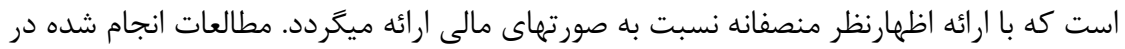

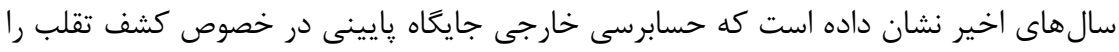

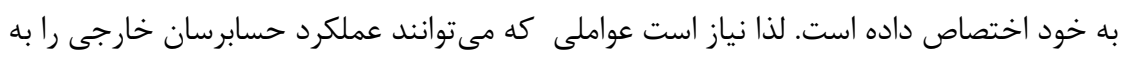
منظور كشف تقلب بهبود بخشند، مورد بررسى قرار گيرد. به اين منظور، متغيرهاى اخلاق حرفه اى(استقلال، عينيت و صداقت) و فلسفه اخلاقى شخصى به عنوان متغيرهاى مستقل، ترديد

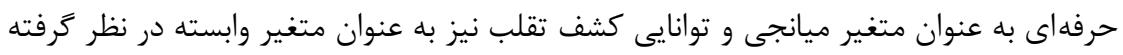

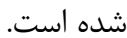

با توجه به نتايج بدست آمده از آزمون فرضيه اول، اخلاق حرفهاى مىتواند به طور مستقيم

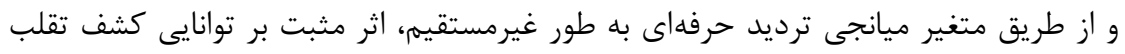

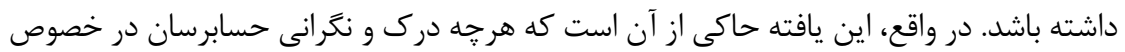
اصول اخلاق حرفهاى بيشتر باشد، توانيى كشف تقلب و سطح ترديد حرفهاى آنها نيز بالاتر است.

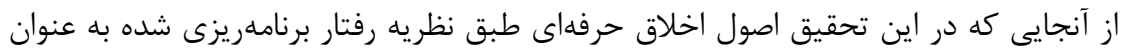
فشار اجتماعى دركشده توسط حسابرسان براى انجام رفتار كشف تقلب(هنجار ذهائ ذهنى) تعريف

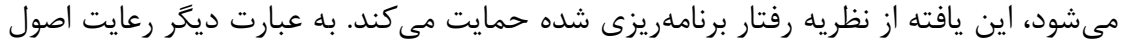

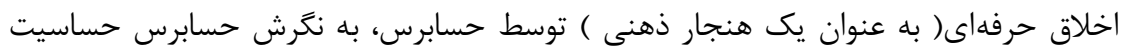

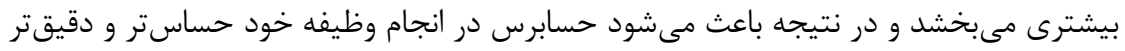

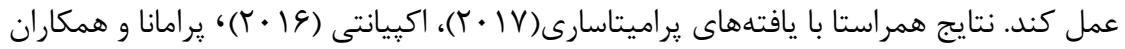

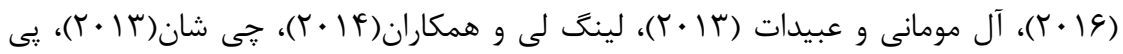

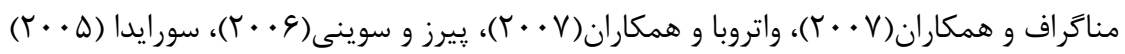

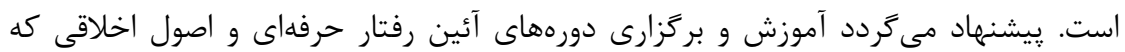


مىتواند رعايت اخلاق حرفهاى توسط حسابرسان در تمامى سطوح را بهبود ببخشد؛ همجنين

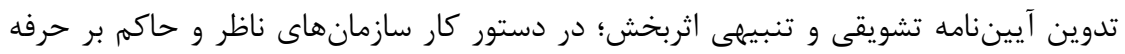

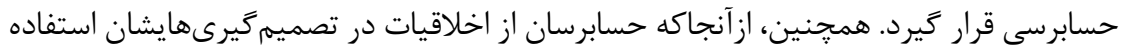
مى كنند و با گسترش و تقويت اخلاق در بين دانشجويان حسابدارى كه حسابرسان آينده هستند

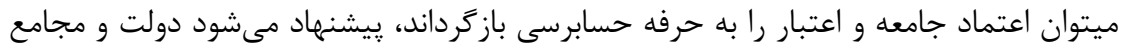

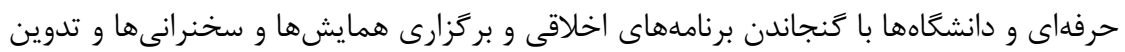

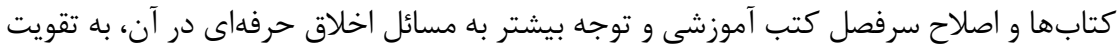
يايههاى اخلاقى و گسترش اخلاقيات اقدامات بسزايى داشته باشند.

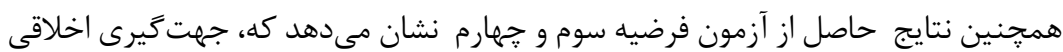

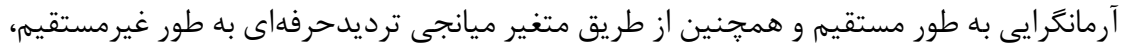

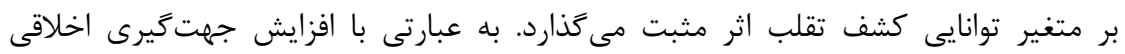

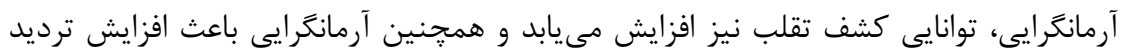

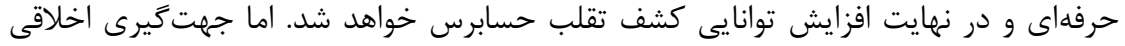

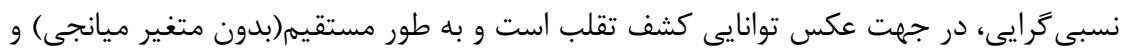

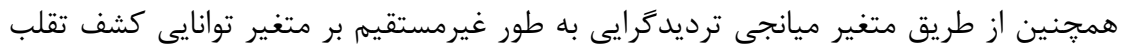

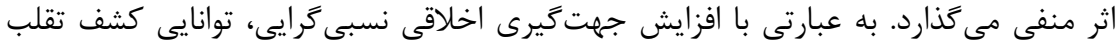

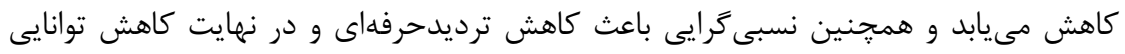

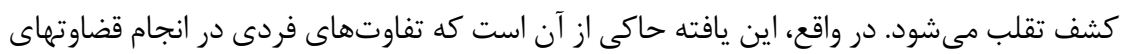
اخلاقى بر توانايى كشف تقلب حسابرسان تاثير مى گذارد. به عبارت ديخر از آنجايى كه آرمانكر اهاها

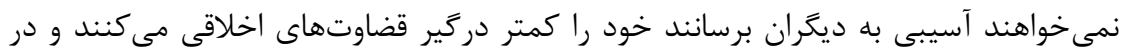

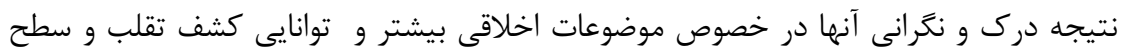

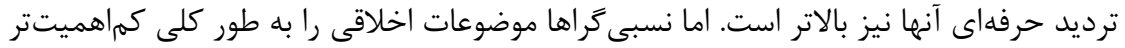

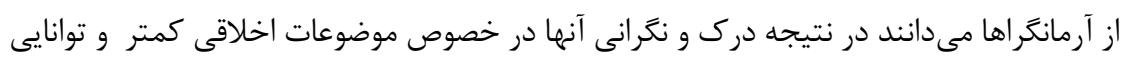

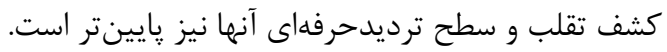

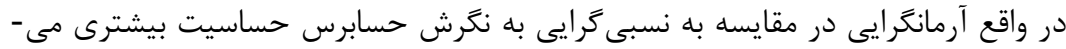

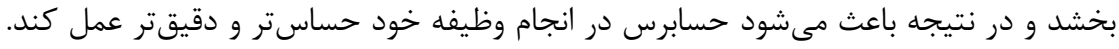

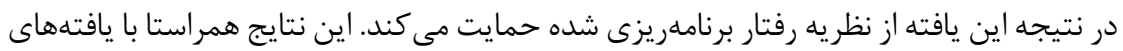

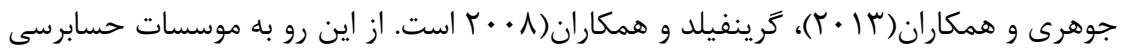

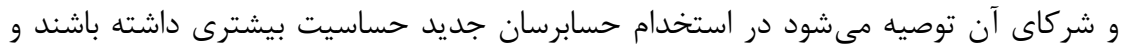

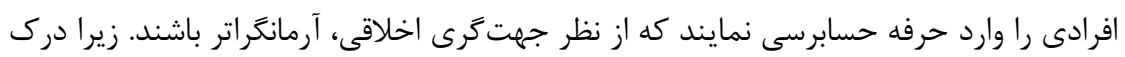


ياشائى فشتالى و همكاران، بررسى تاثير اخلاق حرفه اى و فلسفه اخلاقى شخصى بر توانايى كثف تقلب... rv

و نكرانى اين افراد در خصوص موضوعات اخلاقى بيشتر و توانايى كشف تقلب و سطح ترديد

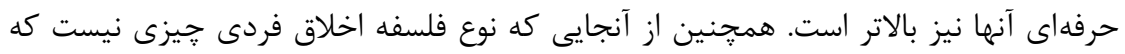

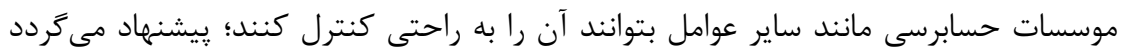

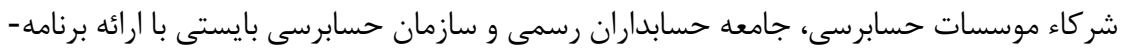

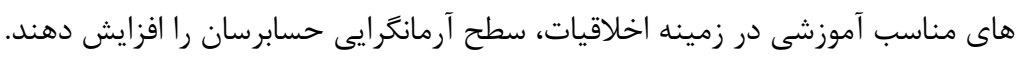

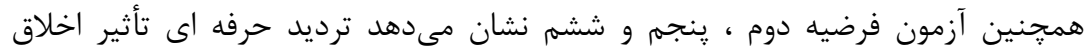

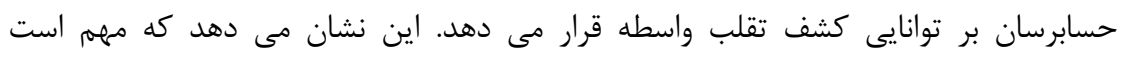

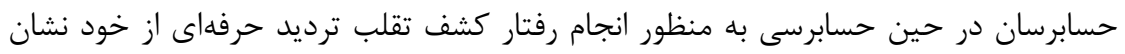

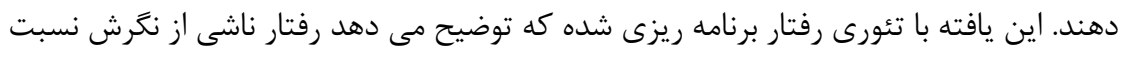

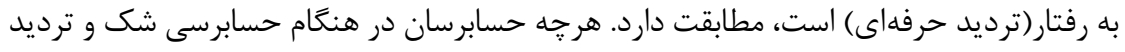

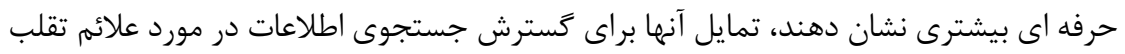

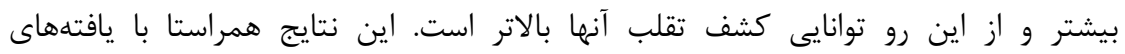

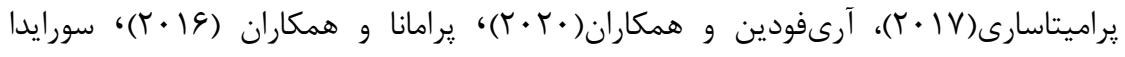

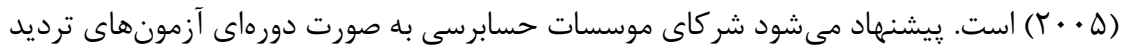

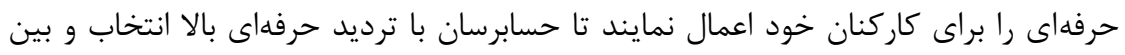

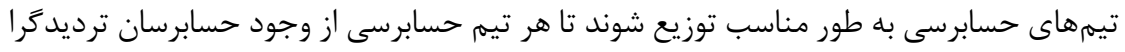

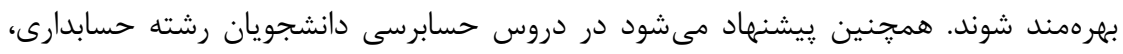

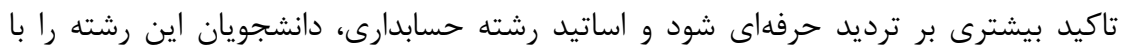

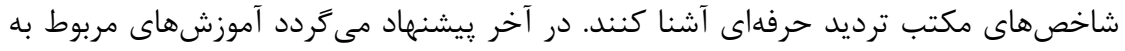

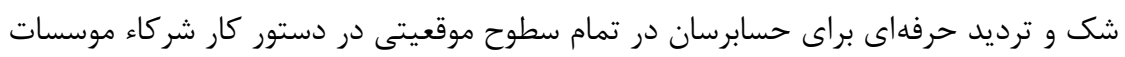

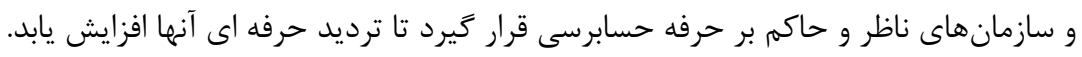

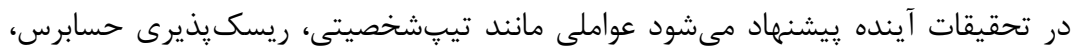

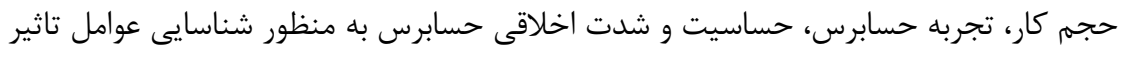

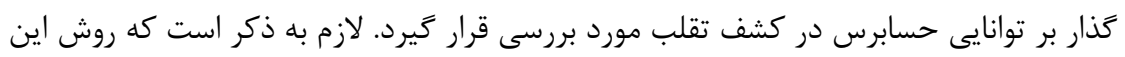

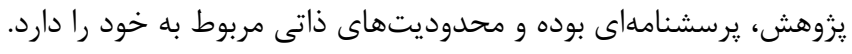

V - Vقدير و تشكر و ملاحظات اخلاقى

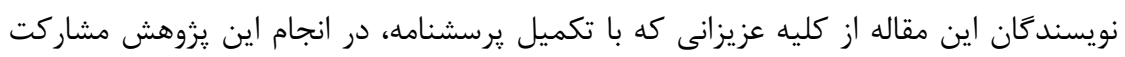

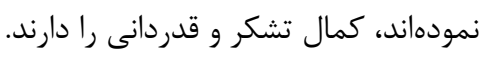




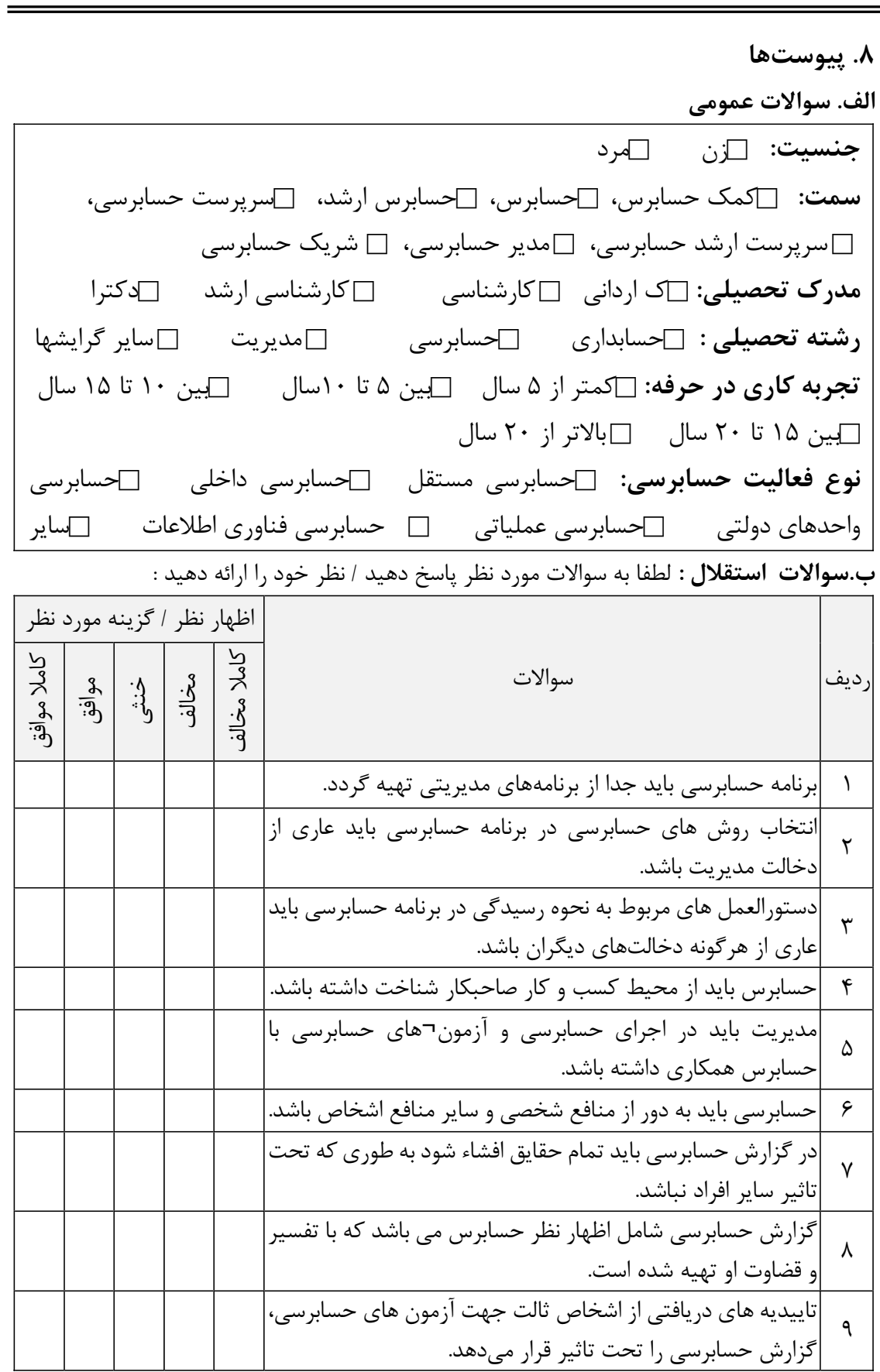


ياشائى فشتالى و همكاران، برر سى تاثير اخلاق حرفه اى و فلسفه اخلاقى شخصى بر توانايى كثف تقلب... وسب

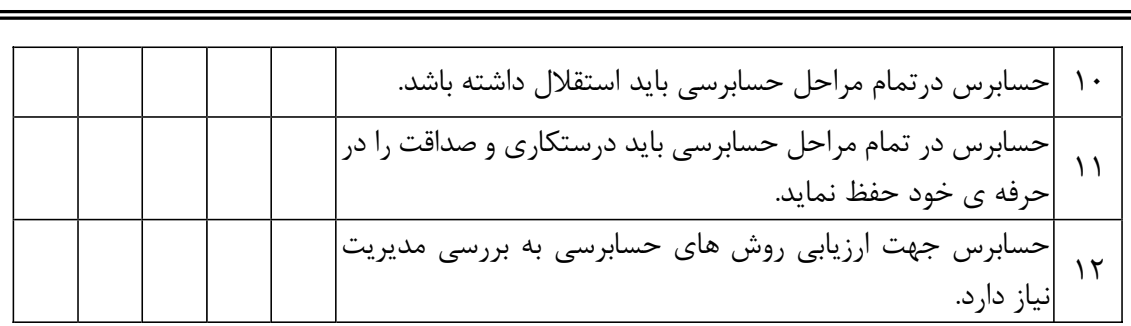

ج.سوالات عينيت(بىطرفى) لطفا به سوالات مورد نظر ياسخ دهيد / نظر خود را ارائه دهيد :

\begin{tabular}{|c|c|c|c|c|c|c|}
\hline \multicolumn{5}{|c|}{ اظهار نظر / زَينه مورد نظر } & \multirow[t]{2}{*}{ سوالات } & \multirow[t]{2}{*}{ | رديف } \\
\hline $\begin{array}{l}\frac{3}{3} \\
\frac{1}{3} \\
\frac{3}{9}\end{array}$ & $\frac{2}{9}$ & $\therefore$ & $\frac{1}{9}$ & $\begin{array}{l}\frac{b}{3} \\
\lambda \\
. \beta \\
.9 \\
.9\end{array}$ & & \\
\hline & & & & & 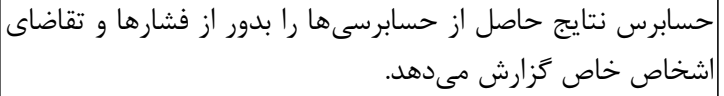 & Ir \\
\hline & & & & & 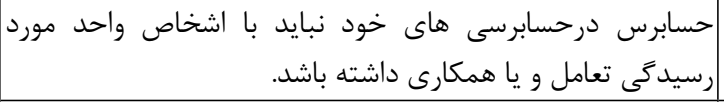 & 14 \\
\hline & & & & & حسابرس در حسابرسىهاى خود نبايد از كسى جانبدارى كند. & 10 \\
\hline & & & & & |حسابرس بايد قابل اعتماد باشد . & 19 \\
\hline & & & & & كند. حسابرس نبايد تحت تاثير حرفحهاى ديخران باشد و به آنها توجه & IV \\
\hline & & & & & هدف حسابرس از حسابرسى بايد كشف خطاها و اشتباهات باشد. & 11 \\
\hline & & & & & حسابرس سياست ها و ضوابط خود را در حسابرسى حفظ مى كند. & 19 \\
\hline & & & & & | حسابرس در انجام حسابرسى بايد از ذهن منطقى و استدلال & $r \cdot$ \\
\hline
\end{tabular}

د.سوالات صداقت و درستى لطفا به سوالات مورد نظر هاسخ دهيد / نظر خود را ارائه دهيد :

\begin{tabular}{|c|c|c|c|c|c|c|}
\hline \multicolumn{5}{|c|}{ اظهار نظر / گزينه مورد نظر } & \multirow[b]{2}{*}{ سوالات } & \multirow[b]{2}{*}{$\hat{\jmath}^{\circ}$} \\
\hline $\begin{array}{l}\frac{b}{3} \\
\lambda \\
\frac{2}{9} \\
\frac{9}{9}\end{array}$ & $\frac{2}{9}$ & $\therefore$ & $\frac{.3}{.9}$ & $\begin{array}{l}b \\
3 \\
\lambda \\
.5 \\
.9\end{array}$ & & \\
\hline & & & & & نظارت و كنترل نباشرس بايد قوانين و مقررات را رعايت نمايد حتى اگر بر روى آن & TI \\
\hline & & & & & حسىدهند. & Tr \\
\hline & & & & & حسابرس همه وقايع، حتى اگر صحيح نباشد را قبول نميكند. & r \\
\hline
\end{tabular}


دو فصلنامه حسابدارى ارزشى و رفتارى، سال ينجم، شماره دهم، پإييز و زمستان وجسا

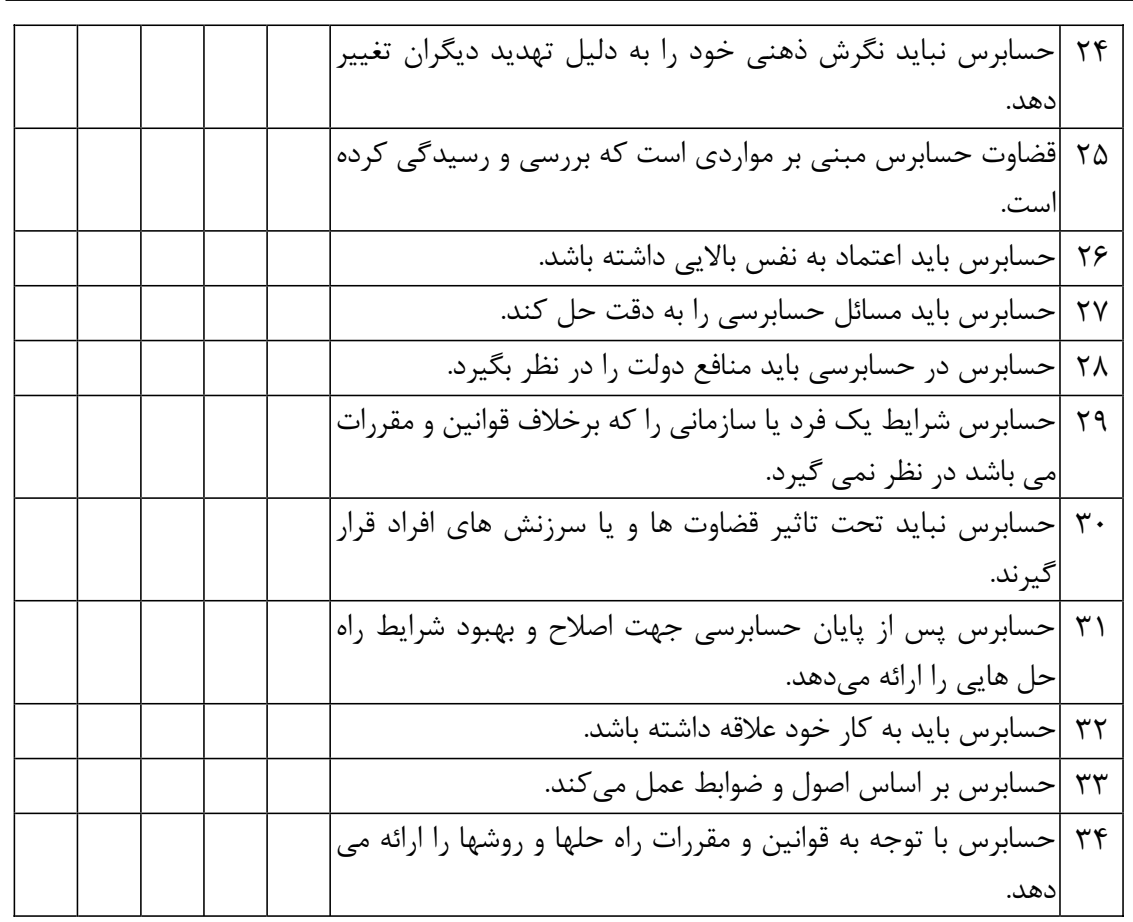

ه.ترديدحرفهاى لطفا به سوالات مورد نظر ياسخ دهيد / نظر خود را ارائه دهيد :

\begin{tabular}{|c|c|c|c|c|c|c|}
\hline \multicolumn{5}{|c|}{ اظهار نظر / گزينه مورد نظر } & \multirow[b]{2}{*}{ سوالات } & \multirow[b]{2}{*}{$\hat{\mathfrak{g}}$} \\
\hline $\begin{array}{l}\frac{3}{3} \\
\frac{\lambda}{2} \\
\frac{\pi}{9}\end{array}$ & $\frac{3}{9}$ & $\hat{y}$ & .9 & 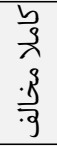 & & \\
\hline & & & & & حسابرس نبايد بيش از حد به صاحب كار نزديك شود. & $\mathrm{r \omega}$ \\
\hline & & & & & حسابرس نبايد توضيحات كوركورانه، از صاحبكاران را قبول نمايد . & re \\
\hline & & & & & نحرش ترديد حرفه در تمام مراحل حسابر كندى، روشهاى حسابرسى را بايد با & rV \\
\hline & & & & & |مورد سوال و ارزيابى ذهن نقادانه قرار دهرانه خود بايد دائما شواهد حسابرسى را & rی \\
\hline & & & & & 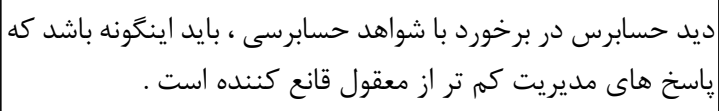 & rq \\
\hline
\end{tabular}




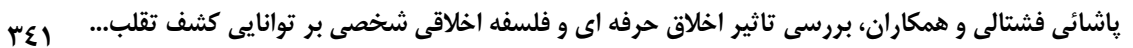

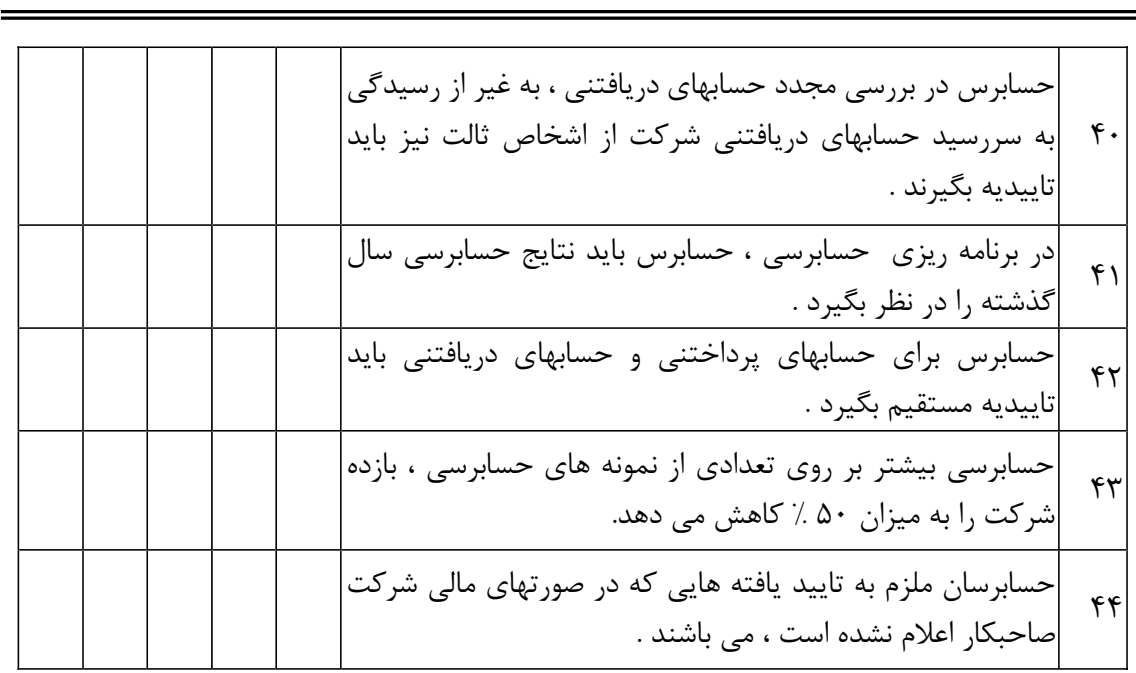

ر.آرمانگر ايى و نسبى

\begin{tabular}{|c|c|c|c|c|c|c|}
\hline & مورد & كزين & لـــــر & & & \\
\hline $\begin{array}{l}b \\
\frac{3}{2} \\
\frac{2}{9}\end{array}$ & $\frac{2}{9}$ & $\therefore\}$ & 歺 & $\begin{array}{l}\frac{b}{3} \\
\frac{\lambda}{\beta} \\
.9 \\
.9\end{array}$ & سوالات & رديف \\
\hline & & & & & |ديخران شخص جـى بايد مطمئن باشد كه فعاليت هايش به صورت عمد به & id \\
\hline & & & & & شبايد با در مخاطره قرار دادن ديخران، حتى به صورت جزيى مدارا| & \&4 \\
\hline & & & & & | در معرض آسيب قرار دادن ديگران براى كسب سود و منفعت همواره & FV \\
\hline & & & & & |قرار دهد كس نبايد قرد ديكرى را به صورت فيزيكى يا روانى مورد صدمه & $\varphi \wedge$ \\
\hline & & & & & |به خيج كس نبايد كارى انجام دهد كه شأن، منزلت و آسايش ديكران & fq \\
\hline & & & & & |نبايد آن رمكن است انجام داد. فعاليتى به يك شخص بى كناه آسيب برساند، & $\Delta \cdot$ \\
\hline & & & & & 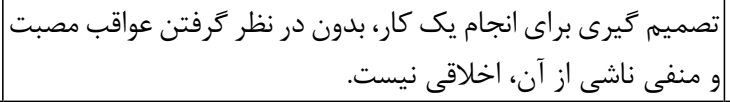 & $\Delta 1$ \\
\hline & & & & & باشد. شأن، منزلت و آسايش افراد بايد مهم ترين دغدغه ى يك جامعه & $\Delta T$ \\
\hline
\end{tabular}




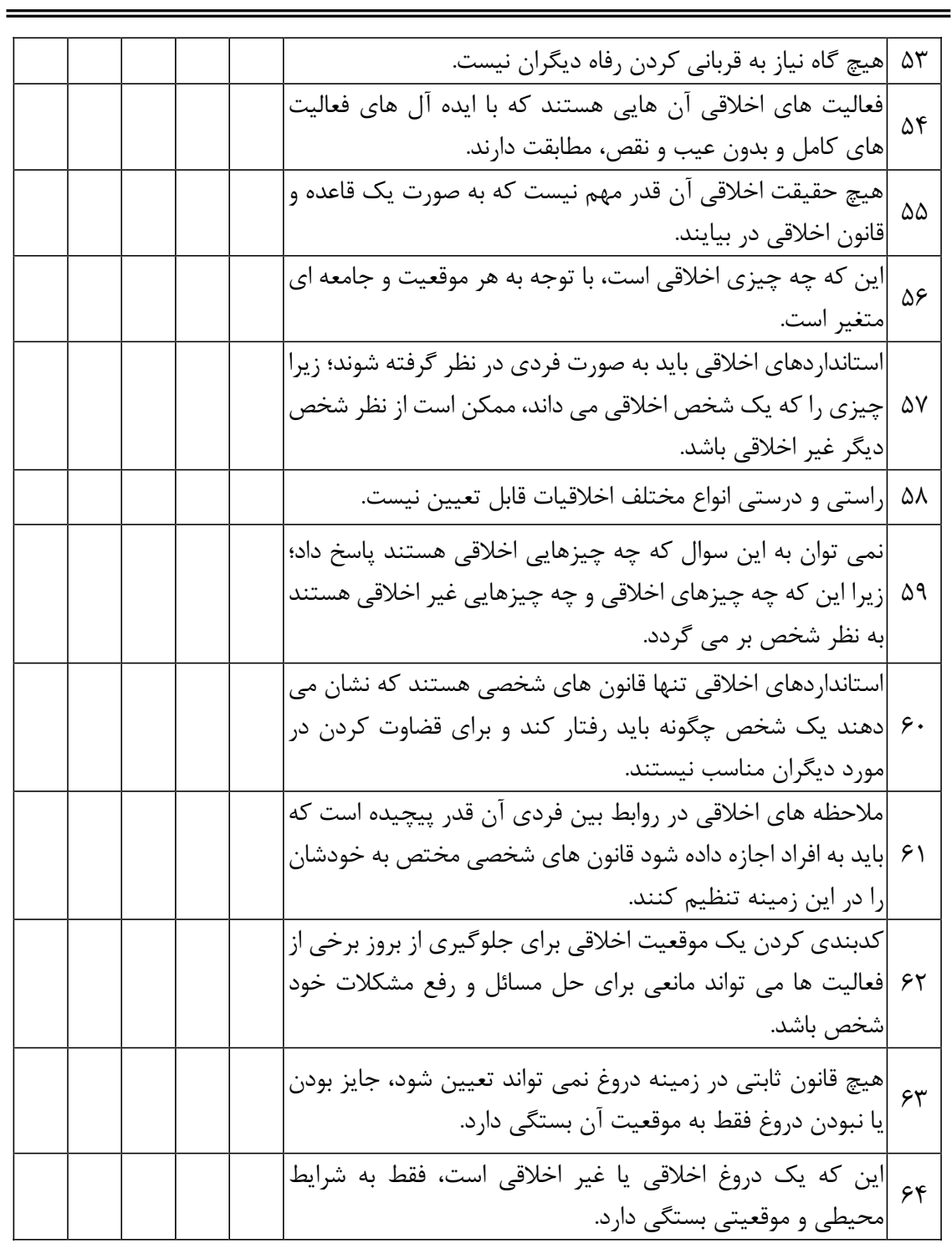


ياشائى فشتالى و همكاران، بررسى تاثير اخلاق حرفه اى و فلسفه اخلاقى شخصى بر توانايى كثف تقلب... سعب

ز.توانايى كشف تقلب اكر موارد زير را مشاهده كرديد تا جه حد جستجو براى كسب اطلاعات را كسترش

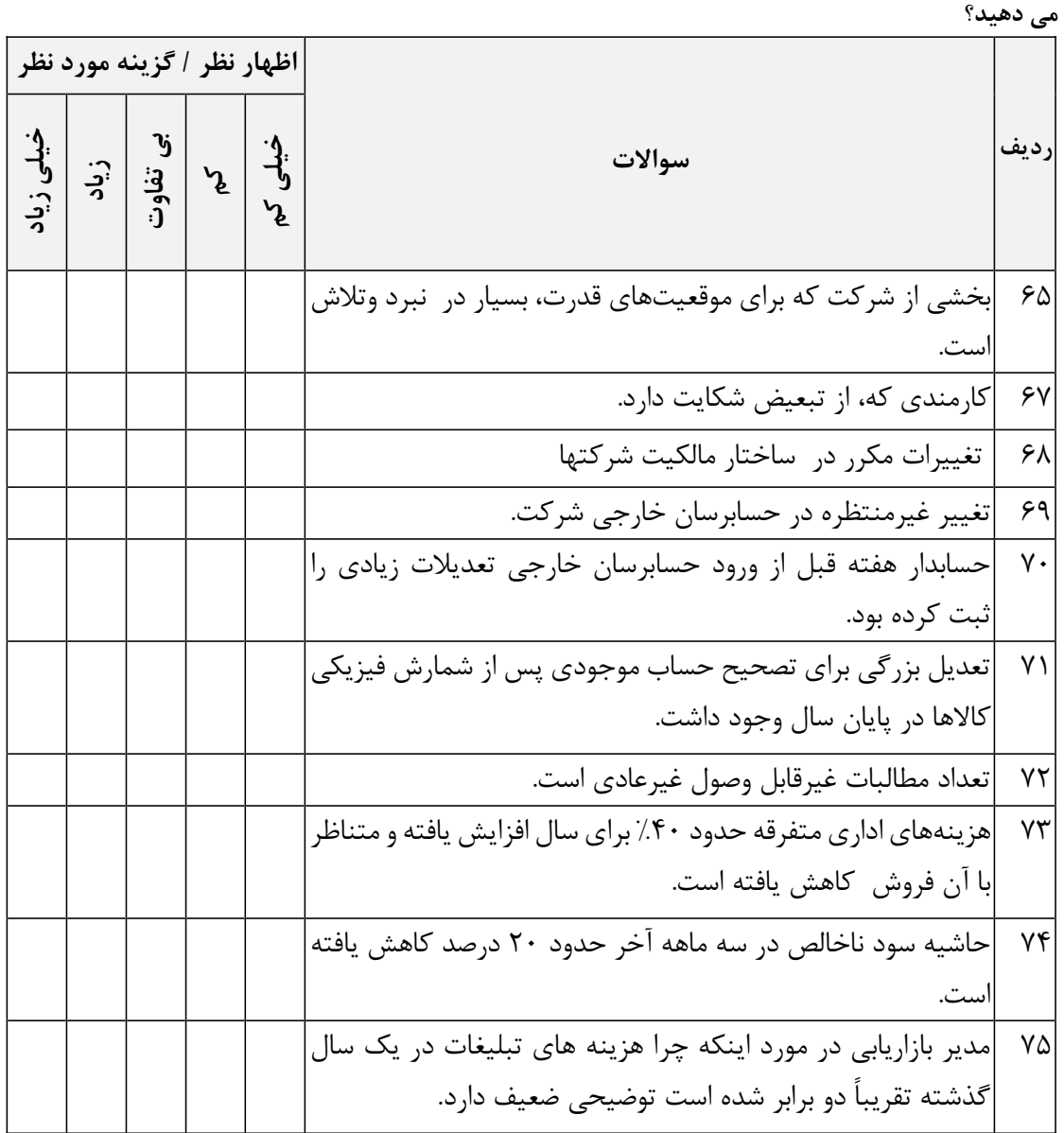

فهرست منابع

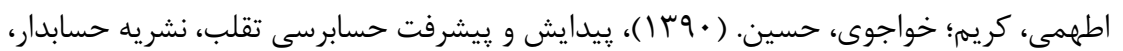

دوره צr، شماره

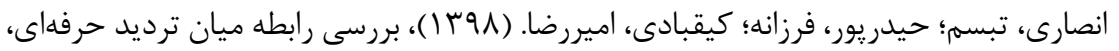

سطح اطمينان و قضاوتها و تصميمات توام با ترديد حسابرس .دانش حسابرسى، دورئ، دوره

19، شمار0 VV، صص TYA-rVF. 
بنى مهد, بهمن؛ كدخدايى اليادران، مزده. ( - F )، رابطه جهت كيرى ارزشى، عواطف مثبت و

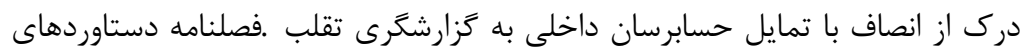

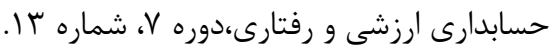

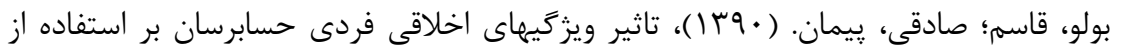

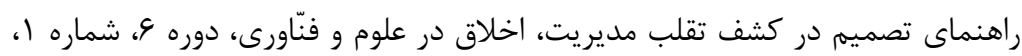

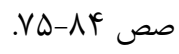

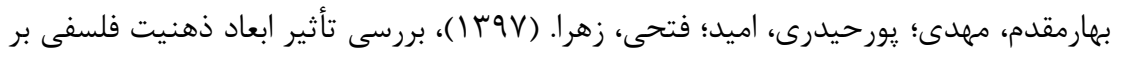

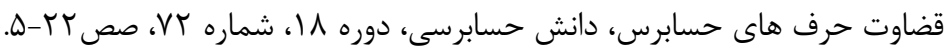

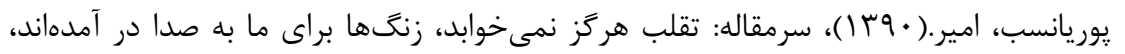

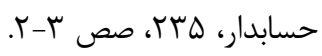

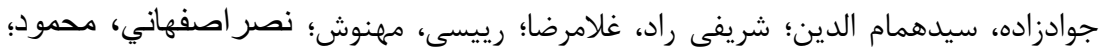

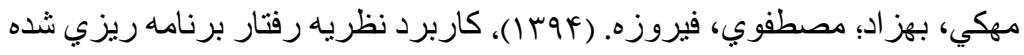

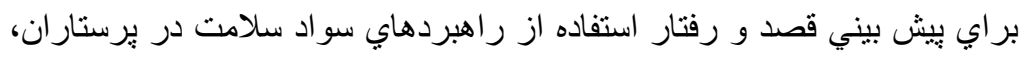

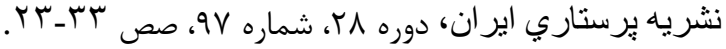

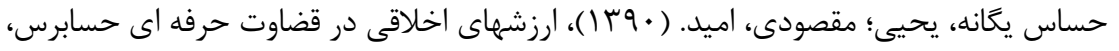

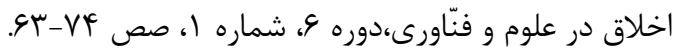

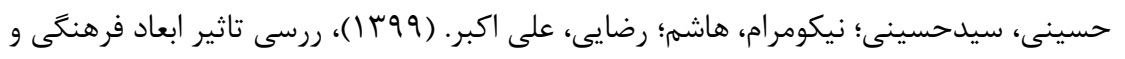

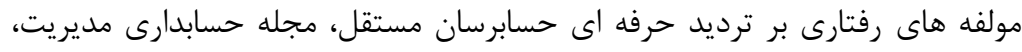

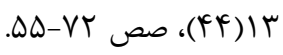

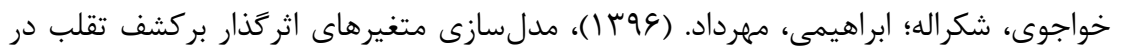

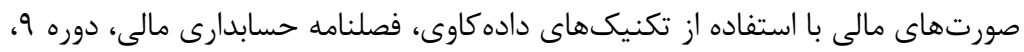

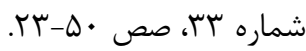

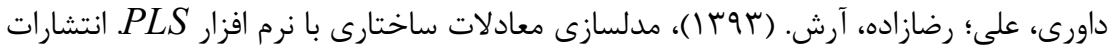

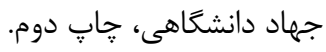

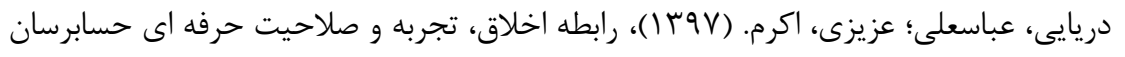

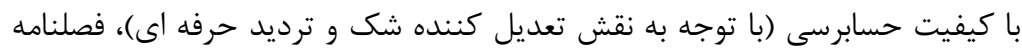

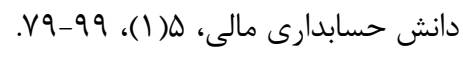

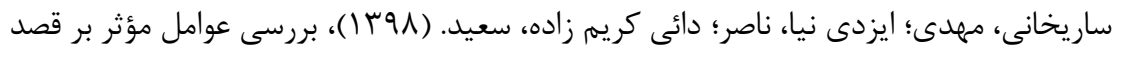

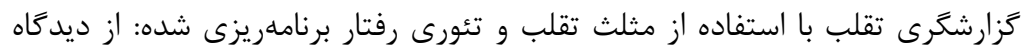

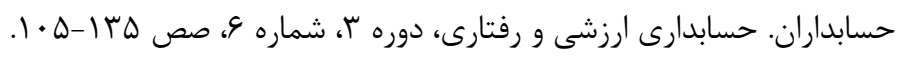




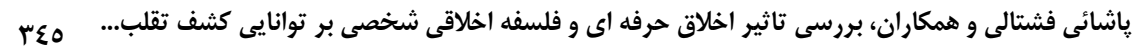

$$
\begin{aligned}
& \text { سياسى، سحر؛ نجفى، فائزه. (ه (ه ))، بررسى تاثير اخلاق حسابرسان بر كشف دستكارى اطلاعات }
\end{aligned}
$$

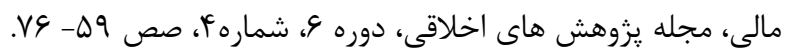

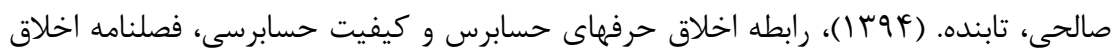

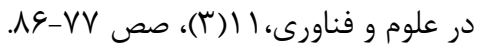

$$
\begin{aligned}
& \text { علىيناه، حكيمه. (99 (1)، تاثير ميزان تحصيلات حسابرسان بر استرس حسابرس و و كيفيت }
\end{aligned}
$$

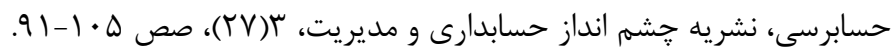

$$
\begin{aligned}
& \text { فخارى، حسين؛ اسكو، وحيد. (VQYI)، تقلب در صورتهاى مالى: نياز به تغيير الكو به سمت }
\end{aligned}
$$

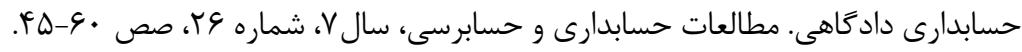

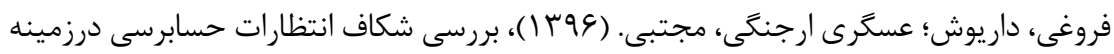

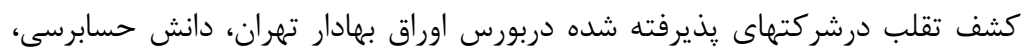

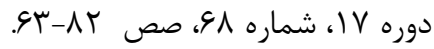

$$
\begin{aligned}
& \text { كاشانى يور، محمد؛ كرمى، غلامرضا؛ خنيفر، حسين؛ شعبانى، كيوان. (1) (1)، بررسى قصد } \\
& \text { هشداردهى حسابرسان مستقل درباره خطاكارى: كاربرد نظريه رفتار برنامه ريزى شده، }
\end{aligned}
$$

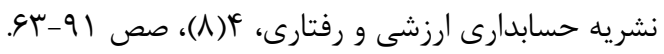

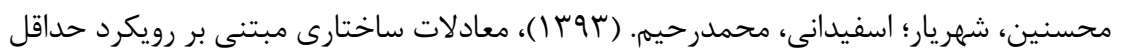

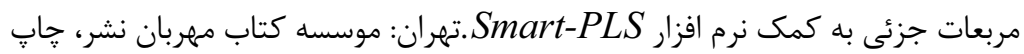

$$
\begin{aligned}
& \text { اول. } \\
& \text { نقش بندى، نادر؛ سادات غفارى، منصوره ؛ يوسف يور، فاطمه. (99 ()، بررسى رابطه استقلال، }
\end{aligned}
$$

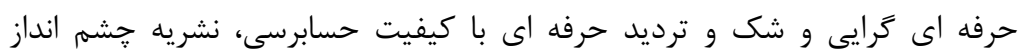

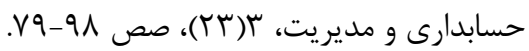

Ajzen, I. 2011. The theory of planned behaviour: Reactions and reflections, Psychology \& Health, 26(9): 1113-1127

Al Momani, M. A., and M. I. Obeidat. 2013. The effect of auditors' ethics on their detection of creative accounting practices: A field study. International Journal of Business and Management, 8(13):118-136.

Albrecht, W. S., G. W. Wernz, and T. L. Williams. 1995. Fraud: Bringing light to the dark side of business. Irwin Professional Pub.

American Institute of Certified Public Accountants. 1997. Due professional care in the performance of work. SAS No. 1, AU Section 230, NY: AICPA. 
American Institute of Certified Public Accountants. 2002. SAS 99: Consideration of Fraud in a Financial Statement Audit. New York, NY: AICPA.

Anofe, A.O.; I. Ukpebor and N. Ogbomo. (2015). The effect of Accounting Ethics in Improving Auditor Professional Skepticism, International Journal of Advanced Academic Research, 1(2): 1-16.

Arifuddin, R. H., and A. Indrijawati. 2020. Auditor Experience, Work Load, Personality Type, and Professional Auditor Skepticism Against Auditors' Ability In Detecting Fraud. Journal of Talent Development and Excellence, 12(2): 1878-1890.

Arumega Zarefar. (2016). Paper of the Influence of Ethics ,Experience and competency toward the Quality of Auditing with Professional Auditor Skepticism as a Moderating Variable .3rd Global Conference on Business and Social Science 219: 828-832.

Association of Certified Fraud Examiners (ACFE). 2018. Report to the Nations on Occupational Fraud and Abuse. Global Fraud Study.

Bologna, G. J., and R. J. Lindquist. 1995. Fraud Auditing and Forensic Accounting: New Tools and Techniques. New York, NY: John Wiley \& Sons, Inc. 2nd ed.

Braun, R. L. (2000). The effect of time pressure on auditor attention to qualitative aspects of misstatements indicative of potential fraudulent financial reporting. Accounting, Organizations and Society, 25(3):243259.

Brown, J. O., J. Hays, and M. T. Stuebs. 2016. Modeling accountant whistleblowing intentions: applying the theory of planned behavior and the fraud triangle, Accounting and the Public Interest, 16 (1): 28-56.

Carthy, I. N. 1997. Professional Ethics Code Conflict Situations: Ethical and Value Orientation of Collegiate Accounting Students. Journal of Business Ethics 16:1467-1473.

Cavusoglu, K., and Angaykutluk, F. 2020. The effect of professional skepticism and ethics on the ability to detect creative accounting. Prestige International Journal of Management \& IT-Sanchayan, 9(1), 70-91.

DeZoort F. T. and P.D. Harrison. 2008. An Evaluation of Internal Auditor Responsibility for Fraud Detection. The Institute of Internal Auditors Research Foundation.

Farag, M. S., and R. Z. Elias. 2012. The Impact of Accounting Students' Professional Skepticism on Their Ethical Perception of Earnings Management. Research on Professional Responsibility \& Ethics in Accounting, 16: 185-200.

Fernando M. and R. Chowdhury. 2010. The relationship between spiritual well-being and ethical orientations in decision making: an empirical 


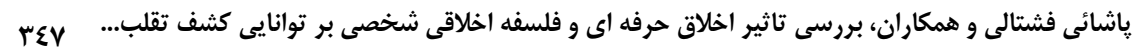

study with business executives in Australia. Journal of Business Ethics; 95(2): 211-225.

Fullerton, R., and C. Durtschi. 2004. The effect of professional skepticism on the fraud detection skills of internal auditors. Available at SSRN 617062.

Fussaro, P. C., and R. M. Miller. 2002. What Went Wrong At Enron: Everyone's Guide to the Largest Bankruptcy in U.S. History. NJ: John Wiley and Sons, Inc.

Gibson, J. L., J. M. Ivancevich, J. H. Donelly, and R. Konopaske. 2012. Organizations: Behavior, Structure, Processes, 14th edition. NY: McGraw-Hill.

Greenfield A., C. Norman, and B. Wier. 2008. The effect of ethical orientation and professional commitment on earnings management behavior. Journal of Business Ethics; 83(3): 419-34.

Hsu, C. S., F. H. Kung., and K. James. 2013. An investigation of auditors' responsibility for fraud detection in Taiwan. Asian Journal of Finance \& Accounting, 5(1): 30-47

Hulland, J. 1999. Use of partial least squares (PLS) in strategic management research: A review of four recent studies. Strategic management journal, 20 (2): 195-204.

Hunt S., and S. Vitell. 1986. A general theory of marketing ethics. Journal of Macromarketing; 6(1): 5-16.

Hurtt, R. K. 2010. Development of a scale to measure professional skepticism.Auditing: A Journal of Practice \& Theory, 29(1): 149-171.

International Auditing \& Assurance Standards Board. 2014. Handbook of International Quality Control, Auditing, Review, Other Assurance, \& Related Services Pronouncements, 2014 edition, vol.1. NY: International Federations of Accountants.

Johari R., Z. Mohd Sanusi, and C. Vincent. 2017. Effects of auditors' ethical orientation and self interest independence threat on the mediating role of moral intensity and ethical decision-making process. International Journal of Auditing; 21(32): 38-58.

Johari R., Z. Mohd Sanusi, R. Abdul Rahman, and N. Omar. 2013. Auditors' independence, experience and ethical judgments: the case of Malaysia. Journal of Business and Public Policy; 8(1): 100-19.

Kung, F.H., and C. L. Huang. 2013. Auditors' Moral Philosophies \& Ethical Beliefs. Management Decision, 51 (3) :479 - 500.

Lisic L.L., S.D. Silveri, Y. Song, and K. Wang. 2014. Accounting fraud, auditing, and the role of government sanctions in China. JBR-08209; No of Pages 10(2014 Elsevier Inc. All rights reserved). 
Marques P. and J. Azevedo-Pereira. 2009. Ethical ideology and ethical judgments in the Portuguese accounting profession. Journal of Business Ethics; 86(2): 212-227.

Matsumura, E. M., and R. R. Tucker. (1992). Fraud detection: A theoretical foundation. Accounting Review, 67(4): 753-782.

Nasution, H., and D. Fitriany. 2012. Effect of Workload, Audit Experience and Personality Type on Professional Skepticism and Auditor's Ability to Detect Fraud. Jurnal Online Mahasiswa Fakultas Ekonomi Universitas Riau, 3(1): 1235-1249.

Okpianti, C. N. 2016. The Influence of Auditor's Experience, Ethic of Profession and Personality toward Auditor's Professional Skepticism \& Auditor's Capability on Fraud Detection (Empirical Study on Public Accountant Office in Yogyakarta.

Pawitra, D. A. K., and Suhartini, D. 2019. The influence of individual behavioral aspects toward audit judg-ment: the mediating role of selfefficacy. Journal of Economics, Business, \& Accountancy Ventura, 22(2): 264-273.

Pierce, B. and B. Sweeney. 2006. Perceived adverse consequences of quality threatening behaviour in audit firms. International journal of auditing, 10(1): 19-39.

Pincus K.V. 1989. Financial auditing and fraud detection: Implications for scientific data audit, Accountability in Research: Policies and Quality Assurance, 1:1: 53-70.

Ponemon, L. A, 1993 .The Influence of Ethical Reasoning on Auditor/s Perceptions of Management's Competence and Integrity, Advances in Accounting, 11: 1-29

Pramana, A. C., G. Irianto, and G. Nurkholis. 2016. The Influence Of Professional Skepticism, Experience and Auditors Independence On The Ability To Detect Fraud. Imperial Journal of Interdisciplinary Research, 2 (11): 1438-1447.

Pramitasari, A. P., Sukoharsono, E. G., \& Djamhuri, A. 2017. The influence of auditor's personality types, experience, ethics, and gender on fraud detection capability: Study of Big Four public accounting firm in Indonesia. Imperial Journal of Interdisciplinary Research (IJIR), 3(7): 640-653.

Rahnamay Roodpooshti F., H. Nikoomaram, A. Mahfoozi. 2012. Machiavellianism and ccountants ethical approach: Evidence from Iran. Journal of Basic and Applied Scientific Research; 2(10): 1057610581.

Schlenker, B. R., and D. R. Forsyth. 1977. On the Ethics of Psychological Research. Journal of Experimental Social Psychology, Vol. 13, No. 4: 369-396. 
ياشائى فشتالى و همكاران، بررسى تاثير اخلاق حرفه اى و فلسفه اخلاقى شخصى بر توانايى كثف تقلب... وعـ

Shaub, M. K. (1989). An empirical examination of the determinants of auditors' ethical sensitivity (Doctoral dissertation, Texas Tech University).

Shaub, M. K., and J.E. Lawrence. 1996. Ethics, experience and professional skepticism: A situational analysis. Behavioral Research in Accounting, 8: $124-157$.

Siewa, C.S., Z. Chin-Cheal, M. khamar tazilah, A. Lee-Zhi, H, Tong-Pei, and Y. Vensen-Sarah. 2018. A study on the relationship between professional skepticism characteristics and auditors' fraud detection in Malaysian context (Doctoral dissertation, UTAR).

Singhapakdi A., S. Vitell, and G. Franke. 1999. Antecedents, consequences and mediating effects of perceived moral intensity and personal moral philosophies. Journal of the Academy of Marketing Science; 27(1): 19-36.

Sulistiyanti, R., and Y. Yakub. 2020. Can professional skepticism, experience, and training support the ability of internal government supervisors to detect fraud?. Point of View Research Accounting and Auditing, 1(4): 190-196.

Suraida, Ida. 2005. Effect of Ethics, Competence, Audit Experience and Audit Risk on Auditor Professional Skepticism and Accuracy in Providing Public Accountant Opinion. Sosiohumaniora. 7(3): 186-202.

Whittington, O.R., and K. Pany. 2001. Principles of Auditing and Other Assurance Services, 13th edition. NY: McGraw-Hill.

Zarefar, A. 2015. The Influence of Ethics ,Experience and competency toward the Quality of Auditing with Professional Auditor Skepticism as a Moderating Variable .3rd Global Conference on Business and Social Science, 219: 828-832. 